\title{
LEVEL II SCOUR ANALYSIS FOR BRIDGE 33 (BURKTH00130033) on TOWN HIGHWAY 13, crossing ROUNDY BROOK, BURKE, VERMONT
}

U.S. Geological Survey Open-File Report 98-005

Prepared in cooperation with

VERMONT AGENCY OF TRANSPORTATION

and

FEDERAL HIGHWAY ADMINISTRATION

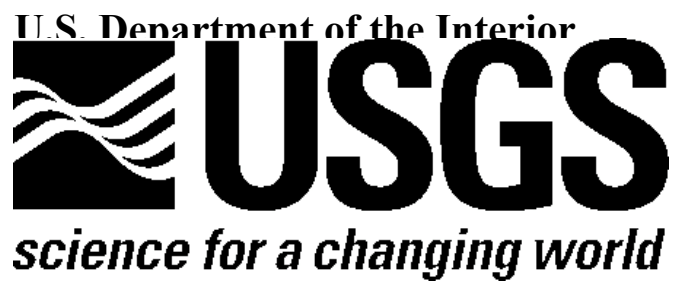




\section{LEVEL II SCOUR ANALYSIS FOR BRIDGE 33 (BURKTH00130033) on TOWN HIGHWAY 13, crossing ROUNDY BROOK, BURKE, VERMONT \\ By ROBERT H. FLYNN AND JAMES R. DEGNAN \\ U.S. Geological Survey Open-File Report 98-005}

Prepared in cooperation with

VERMONT AGENCY OF TRANSPORTATION

and

FEDERAL HIGHWAY ADMINISTRATION 


\title{
U.S. DEPARTMENT OF THE INTERIOR BRUCE BABBITT, Secretary
}

\author{
U.S. GEOLOGICAL SURVEY \\ Mark Schaefer, Acting Director
}

For additional information write to:

District Chief

U.S. Geological Survey 361 Commerce Way

Pembroke, NH 03275-3718
Copies of this report may be purchased from:

U.S. Geological Survey

Branch of Information Services

Open-File Reports Unit

Box 25286

Denver, CO 80225-0286 


\section{CONTENTS}

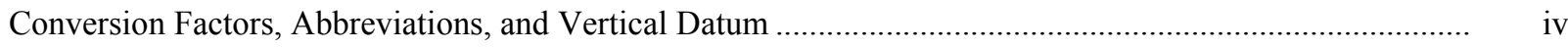

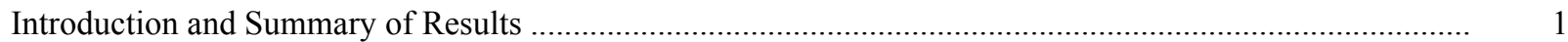

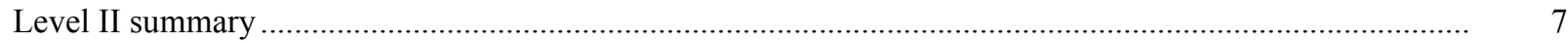

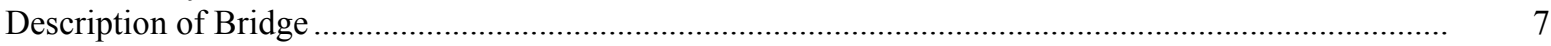

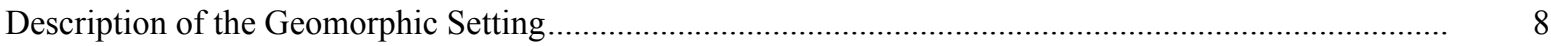

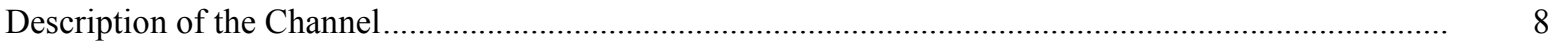

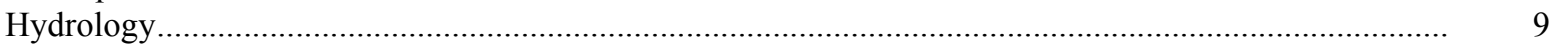

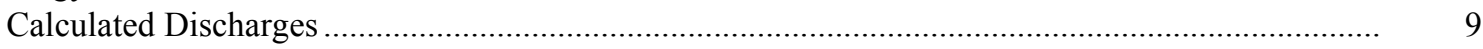

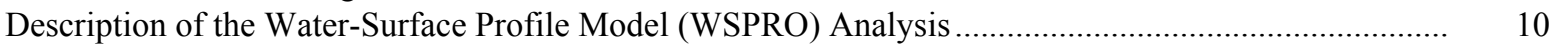

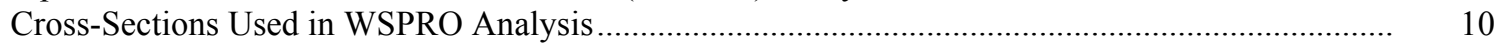

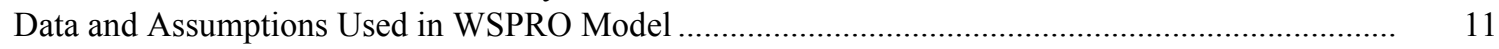

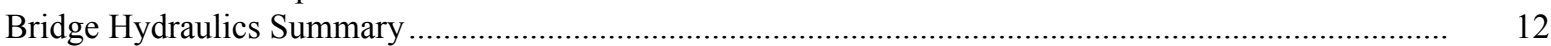

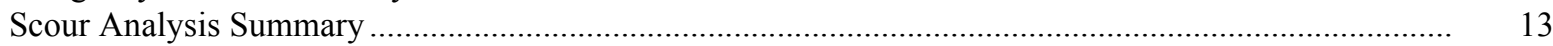

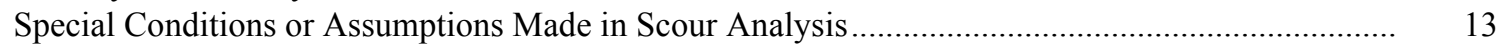

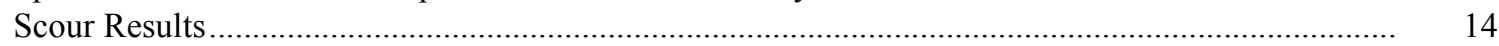

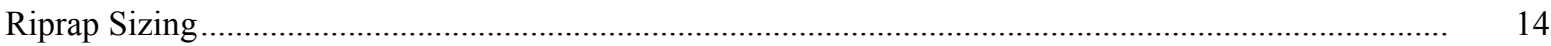

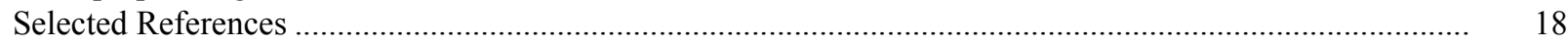

Appendices:

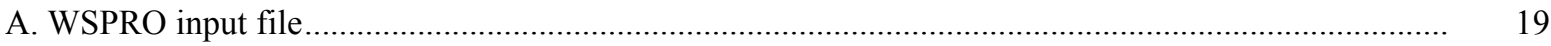

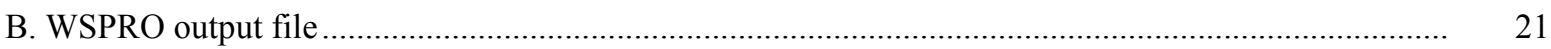

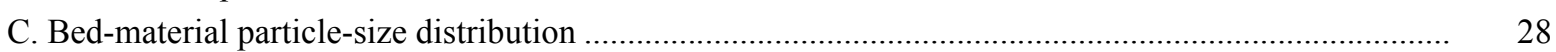

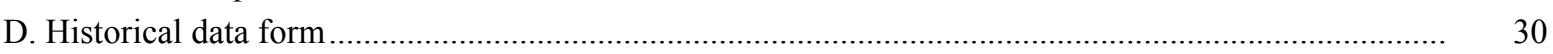

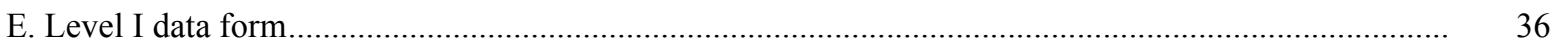

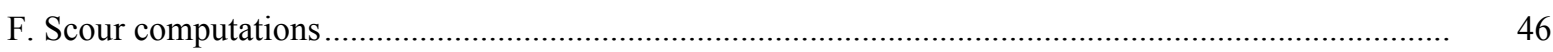

\section{FIGURES}

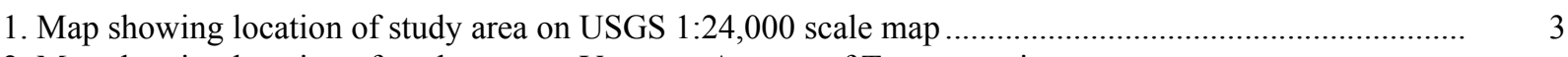

2. Map showing location of study area on Vermont Agency of Transportation town

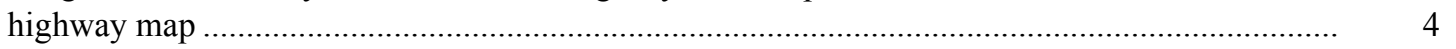

3. Structure BURKTH00130033 viewed from upstream (August 8, 1995) ............................................ 5

4. Downstream channel viewed from structure BURKTH00130033 (August 8, 1995)............................. 5

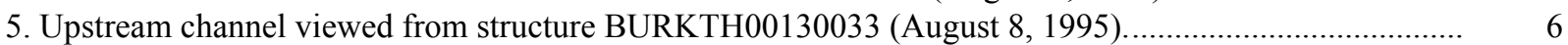

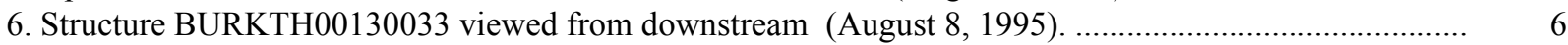

7. Water-surface profiles for the 100- and 500-year discharges at structure BURKTH00130033 on Town Highway 13, crossing Roundy Brook,

Burke, Vermont.

8. Scour elevations for the 100- and 500-year discharges at structure

BURKTH00130033 on Town Highway 13, crossing Roundy Brook,

Burke, Vermont.

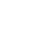

5

6




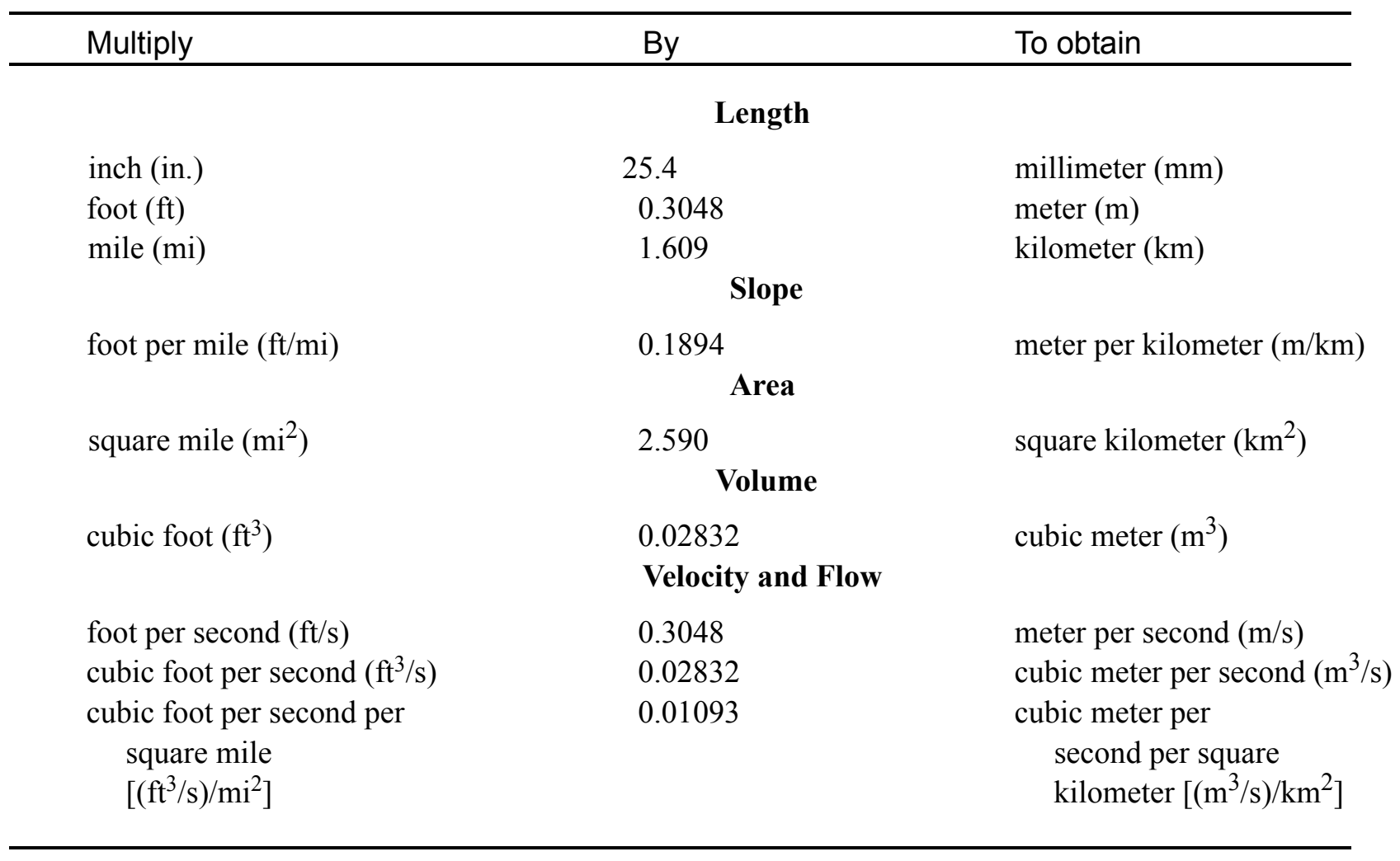

\section{OTHER ABBREVIATIONS}

$\begin{array}{lrlr}\mathrm{BF} & \text { bank full } & \text { LWW } & \text { left wingwall } \\ \mathrm{cfs} & \text { cubic feet per second } & \text { MC } & \text { main channel } \\ \mathrm{D}_{50} & \text { median diameter of bed material } & \text { RAB } & \text { right abutment } \\ \mathrm{DS} & \text { downstream } & \text { RABUT } & \text { face of right abutment } \\ \mathrm{elev} & \text { elevation } & \text { RB } & \text { right bank } \\ \mathrm{f} / \mathrm{p} & \text { flood plain } & \text { ROB } & \text { right overbank } \\ \mathrm{ft}^{2} & \text { square feet } & \text { RWW } & \text { right wingwall } \\ \mathrm{ft} / \mathrm{ft} & \text { feet per foot } & \text { TH } & \text { town highway } \\ \mathrm{JCT} & \text { junction } & \text { UB } & \text { under bridge } \\ \mathrm{LAB} & \text { left abutment } & \text { US } & \text { upstream } \\ \mathrm{LABUT} & \text { face of left abutment } & \text { USGS } & \text { United States Geological Survey } \\ \mathrm{LB} & \text { left bank } & \text { VTAOT Vermont Agency of Transportation } \\ \mathrm{LOB} & \text { left overbank } & \text { WSPRO } & \text { water-surface profile model }\end{array}$

In this report, the words "right" and "left" refer to directions that would be reported by an observer facing downstream. Sea level: In this report, "sea level" refers to the National Geodetic Vertical Datum of 1929-- a geodetic datum derived from a general adjustment of the first-order level nets of the United States and Canada, formerly called Sea Level Datum of 1929.

In the appendices, the above abbreviations may be combined. For example, USLB would represent upstream left bank. 


\title{
LEVEL II SCOUR ANALYSIS FOR BRIDGE 33 (BURKTH00130033) ON TOWN HIGHWAY 13, CROSSING ROUNDY BROOK, BURKE, VERMONT
}

\author{
By Robert H. Flynn and James R. Degnan
}

\section{INTRODUCTION AND SUMMARY OF RESULTS}

This report provides the results of a detailed Level II analysis of scour potential at structure BURKTH00130033 on Town Highway 13 crossing Roundy Brook, Burke, Vermont (Figures 1-8). A Level II study is a basic engineering analysis of the site, including a quantitative analysis of stream stability and scour (U.S. Department of Transportation, 1993). Results of a Level I scour investigation also are included in Appendix E of this report. A Level I investigation provides a qualitative geomorphic characterization of the study site. Information on the bridge, gleaned from Vermont Agency of Transportation (VTAOT) files, was compiled prior to conducting Level I and Level II analyses and is found in Appendix D.

The site is in the White Mountain section of the New England physiographic province in northeastern Vermont. The $7.85-\mathrm{mi}^{2}$ drainage area is in a predominantly rural and forested basin. In the vicinity of the study site, the surface cover upstream and downstream of the bridge is forest.

In the study area, Roundy Brook has an incised, sinuous channel with a slope of approximately $0.02 \mathrm{ft} / \mathrm{ft}$, an average channel top width of $45 \mathrm{ft}$ and an average bank height of $3 \mathrm{ft}$. The channel bed material ranges from gravel to bedrock with a median grain size $\left(\mathrm{D}_{50}\right)$ of $99.0 \mathrm{~mm}(0.325 \mathrm{ft})$. The geomorphic assessment at the time of the Level I and Level II site visit on August 8, 1995, indicated that the reach was stable.

The Town Highway 13 crossing of Roundy Brook is a 30-ft-long, narrow two-lane bridge consisting of one 26-foot steel-beam span (Vermont Agency of Transportation, written communication, March 24, 1995). The opening length of the structure parallel to the bridge face is $24.8 \mathrm{ft}$. The bridge is supported by vertical, concrete abutments with wingwalls. The channel is skewed approximately 60 degrees to the opening while the opening-skew-toroadway is 35 degrees. 
A scour hole approximately $1.0 \mathrm{ft}$ deeper than the mean thalweg depth was observed along the left abutment and upstream left wingwall during the Level I assessment. In addition, there are two other scour holes, approximately $0.5 \mathrm{ft}$ deeper than the mean thalweg depth, which are located at the upstream end of the downstream left wingwall and at the downstream end of the upstream right wingwall. The scour protection measures at the site include type- 1 stone fill (less than 12 inches diameter) along the upstream banks and type-2 stone fill (less than 36 inches diameter) along the downstream left bank. Additional details describing conditions at the site are included in the Level II Summary and Appendices $\mathrm{D}$ and $\mathrm{E}$.

Scour depths and recommended rock rip-rap sizes were computed using the general guidelines described in Hydraulic Engineering Circular 18 (Richardson and Davis, 1995) for the 100- and 500-year discharges. In addition, the incipient roadway-overtopping discharge was determined and analyzed as another potential worst-case scour scenario. Total scour at a highway crossing is comprised of three components: 1) long-term streambed degradation; 2) contraction scour (due to accelerated flow caused by a reduction in flow area at a bridge) and; 3 ) local scour (caused by accelerated flow around piers and abutments). Total scour is the sum of the three components. Equations are available to compute depths for contraction and local scour and a summary of the results of these computations follows.

Contraction scour for all modelled flows ranged from 0.0 to $1.4 \mathrm{ft}$. The worst-case contraction scour occurred at the 100-year discharge. Abutment scour ranged from 1.7 to $7.0 \mathrm{ft}$ along the right abutment and from 9.6 to $11.7 \mathrm{ft}$ along the left abutment. The worstcase abutment scour occurred at the 100-year discharge. Additional information on scour depths and depths to armoring are included in the section titled "Scour Results". Scouredstreambed elevations, based on the calculated scour depths, are presented in Tables 1 and 2. A cross-section of the scour computed at the bridge is presented in Figure 8. Scour depths were calculated assuming an infinite depth of erosive material and a homogeneous particlesize distribution.

It is generally accepted that the Froehlich equation (abutment scour) gives "excessively conservative estimates of scour depths" (Richardson and Davis, 1995, p. 47). Usually, computed scour depths are evaluated in combination with other information including (but not limited to) historical performance during flood events, the geomorphic stability assessment, existing scour protection measures, and the results of the hydraulic analyses. Therefore, scour depths adopted by VTAOT may differ from the computed values documented herein. 


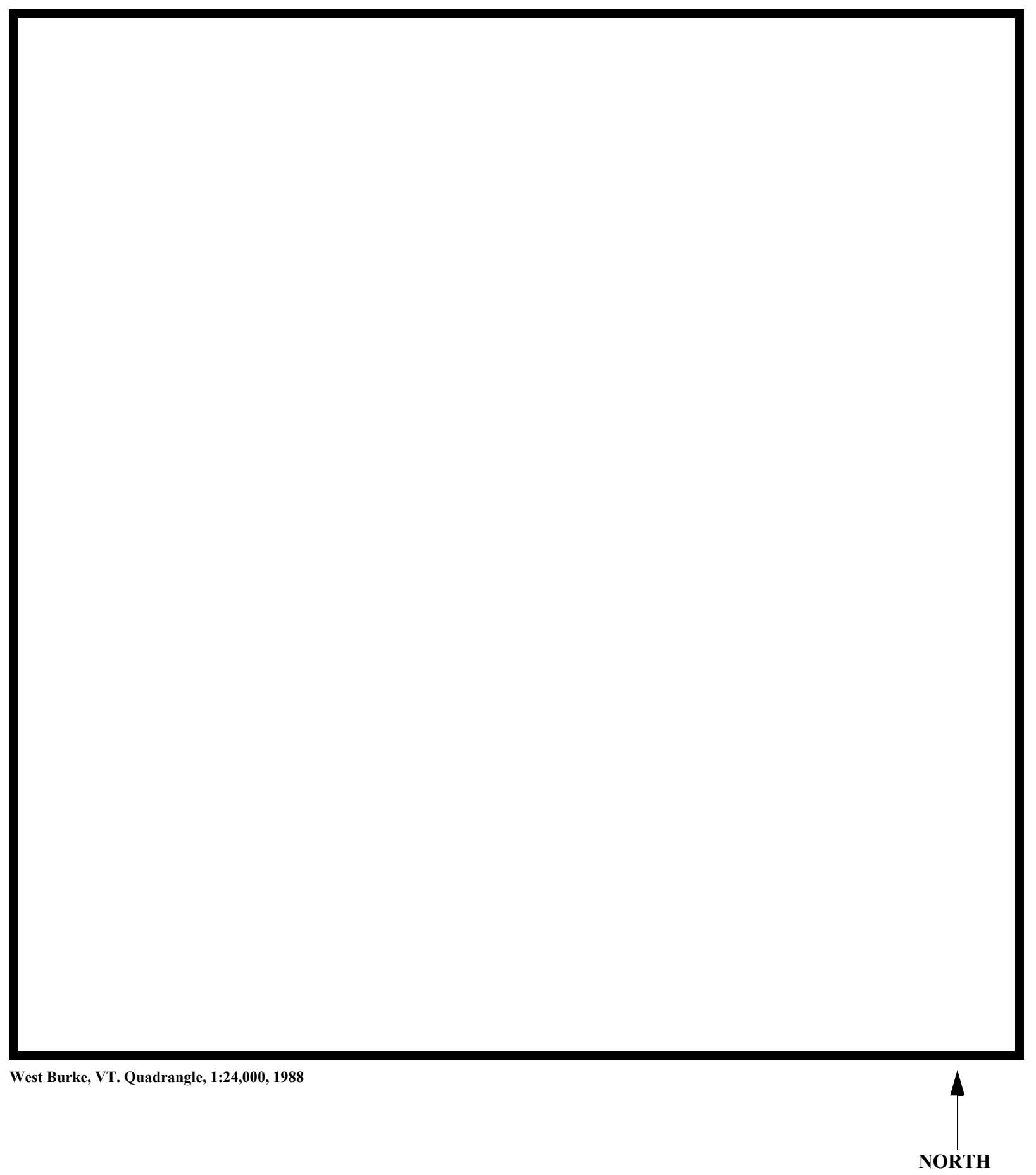

Figure 1. Location of study area on USGS 1:24,000 scale map. 
Figure 2. Location of study area on Vermont Agency of Transportation town highway map. 

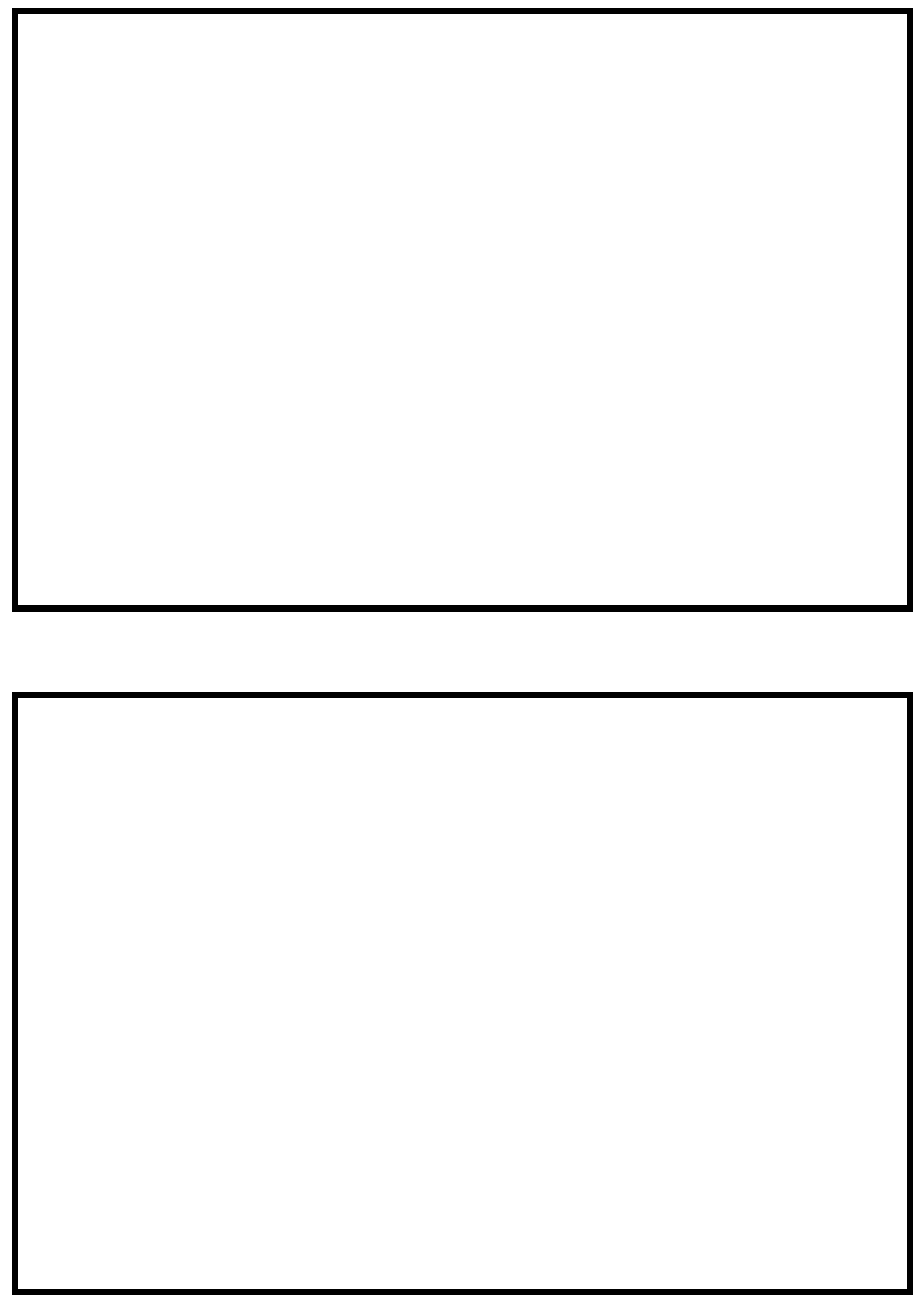

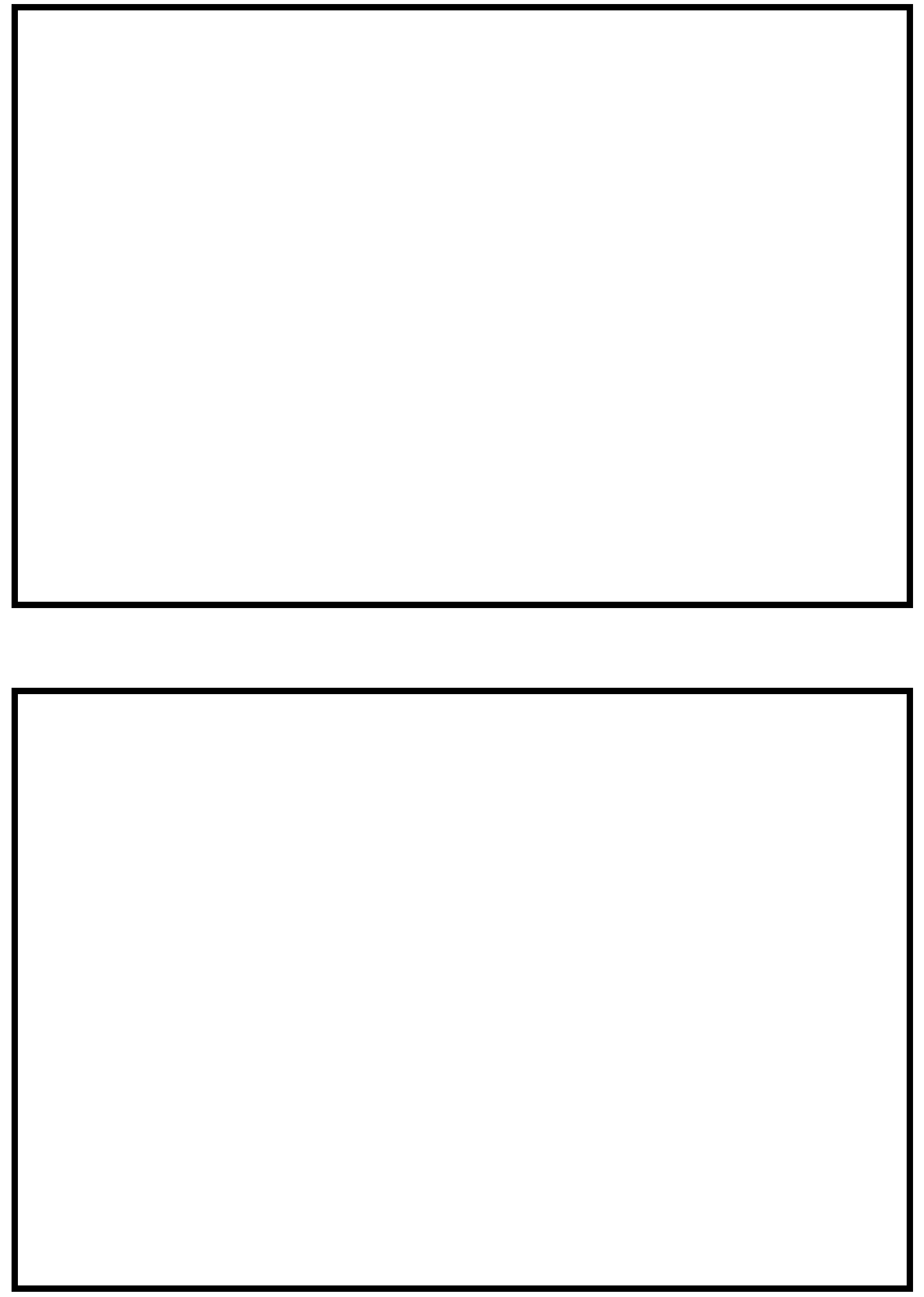


\section{LEVEL II SUMMARY}

\begin{tabular}{llllll} 
Structure Number & \multicolumn{2}{c}{ BURKTH00130033 } & Stream & \multicolumn{3}{c}{ Roundy Brook } \\
& Road & TH13 & District & 7 \\
County & Caledonia & Roann
\end{tabular}

\section{Description of Bridge}

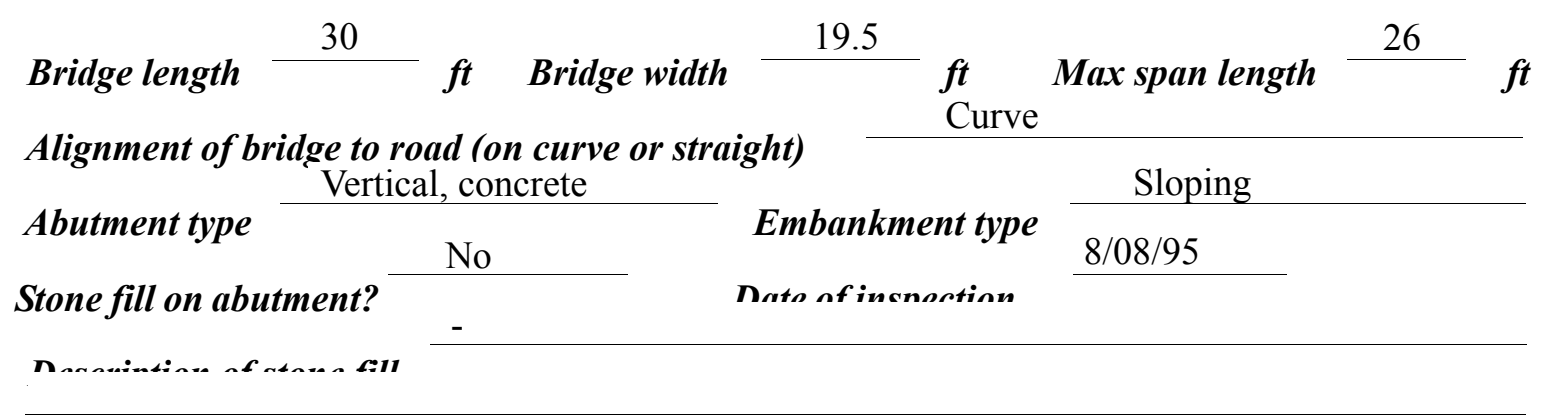

Abutments and wingwalls are concrete. There is an approximately one foot deep scour hole in front of the LABUT and USLWW.

Is bridge skewed to flood flow according to $\mathrm{Y} \quad$ survey?
There is a moderate channel bend in the upstream and downstream reaches. Scour holes have
developed in the locations where the bend impacts the LABUT and wingwalls.

Debris accumulation on bridge at time of Level I or Level II site visit:

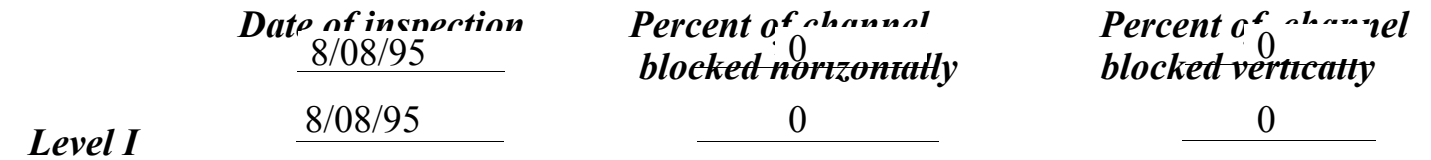

Level II

Moderate. The channel is laterally unstable and sinuous with tree cover and cut-banks evident along the upstream and downstream banks.

Potential for debris

Point bars along the RABUT and upstream left bank constrict the channel at lower Doscriho anv, foaturos noar ar at tho hridoo that mav, affort flow, (includo ahsorvation dato) flows. Observed on 8/08/95. 


\section{Description of the Geomorphic Setting}

General topography The channel is located within a moderate relief valley setting with no

flood plain and steep valley walls on both sides.

Geomorphic conditions at bridge site: downstream (DS), upstream (US)

Date of inspection $\quad 8 / 08 / 95$

DS left: $\quad$ Steep channel bank and valley wall.

DS right: $\quad$ Steep channel bank and valley wall.

US left: $\quad$ Steep channel bank and valley wall.

US right: $\quad$ Steep channel bank and valley wall.

\section{Description of the Channel}

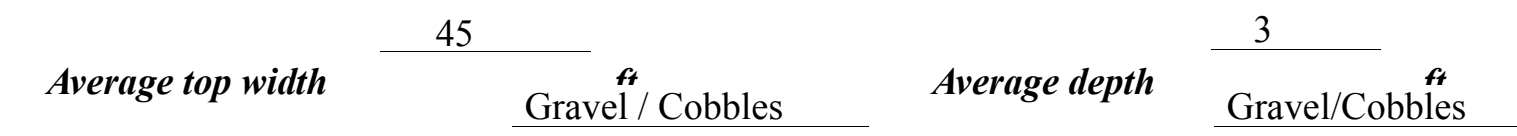

Predominant bed material

Bank material

Sinuous but stable

with semi-alluvial to non-alluvial channel boundaries and a narrow flood plain.

$8 / 08 / 95$

Vegetative co 1 Trees and brušh.

DS left: $\quad$ Trees and brush.

DS right: $\quad$ Trees and brush.

US left: $\quad$ Trees and brush.

US right: $\quad$ Yes

Do banks appear stable? Impact zones and cutt-banks exist along the upstream left bank and the downstream right bank but, the stream is considered to be stable due to the steep valley walls
date of observation. and large bed and bank material which includes bedrock outcrops in many areas along the reach.

The assessment of

8/08/95 noted low flow

conditions are influenced by point bars along the right

Describe any obstructions in channel and date of observation.

abutment and along the upstream left bank. In addition, some debris is caught on boulders in the upstream channel. 


\title{
Hydrology
}

Drainage area $\frac{7.85}{\mathrm{mi}^{2}}$

Percentage of drainage area in physiographic provinces: (approximate)

Physiographic province/section

New England/White Mountain
Percent of drainage area 100

\begin{abstract}
Is drainage area considered rural or urban?
Rural None.

urbanization:-

Describe any significant
\end{abstract}

Is there a USGS gage on the stream of interest?
USGS gage description

No

USGS gage description

USGS gage number

Gage drainage area $\mathrm{mi}^{2}$

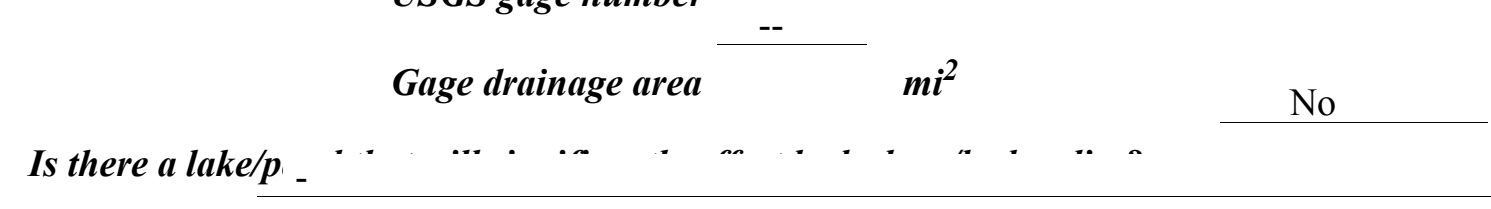

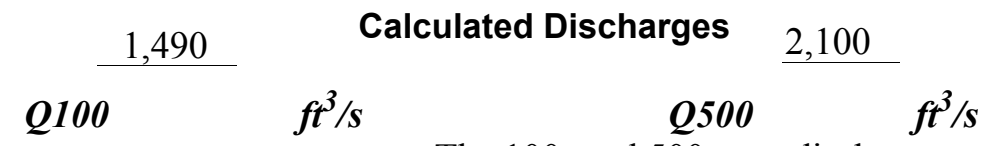

The 100- and 500-year discharges are based on a

drainage area relationship [(7.8/8.1) exp 0.67] with bridge number 10 in Burke. Bridge number

10 crosses Roundy Brook downstream of this site and has flood frequency estimates available from the VTAOT database. The drainage area above bridge number 10 is 8.1 square miles.

These values were selected due to their central tendency when compared to other discharge frequency curves which were developed from empirical relationships and extended to the 500year discharge (Benson, 1962; Johnson and Tasker, 1974; FHWA, 1983; Potter, 1957a\&b; Talbot, 1887). 


\section{Description of the Water-Surface Profile Model (WSPRO) Analysis}

Datum for WSPRO analysis (USGS survey, sea level, VTAOT plans)

USGS survey

Datum tie between USGS survey and VTAOT plans

None

Description of reference marks used to determine USGS datum. $\quad$ RM1 is a chiseled X on

top of the right end of the downstream concrete bridge curb (elev. $501.63 \mathrm{ft}$, arbitrary survey

datum). RM2 is a chiseled $\mathrm{X}$ on top of the left end of the downstream concrete bridge curb

(elev. $500.99 \mathrm{ft}$, arbitrary survey datum).

\section{Cross-Sections Used in WSPRO Analysis}

\begin{tabular}{|c|c|c|c|}
\hline${ }^{1}$ Cross-section & $\begin{array}{c}\text { Section } \\
\text { Reference } \\
\text { Distance } \\
\text { (SRD) in feet }\end{array}$ & $\begin{array}{c}{ }^{2} \text { Cross-section } \\
\text { development }\end{array}$ & Comments \\
\hline EXITX & -21 & 1 & Exit section \\
\hline FULLV & 0 & 2 & $\begin{array}{l}\text { Downstream Full-valley } \\
\text { section (Templated from } \\
\text { EXITX) }\end{array}$ \\
\hline BRIDG & 0 & 1 & Bridge section \\
\hline RDWAY & 13 & 1 & Road Grade section \\
\hline APPRO & 46 & 2 & $\begin{array}{l}\text { Modelled Approach sec- } \\
\text { tion (Templated from } \\
\text { APTEM) }\end{array}$ \\
\hline APTEM & 63 & 1 & $\begin{array}{l}\text { Approach section as sur- } \\
\text { veyed (Used as a tem- } \\
\text { plate) }\end{array}$ \\
\hline
\end{tabular}

${ }^{1}$ For location of cross-sections see plan-view sketch included with Level I field form, Appendix E.

For more detail on how cross-sections were developed see WSPRO input file. 


\section{Data and Assumptions Used in WSPRO Model}

Hydraulic analyses of the reach were done by use of the Federal Highway Administration's WSPRO step-backwater computer program (Shearman and others, 1986, and Shearman, 1990). The analyses reported herein reflect conditions existing at the site at the time of the study. Furthermore, in the development of the model it was necessary to assume no accumulation of debris or ice at the site. Results of the hydraulic model are presented in the Bridge Hydraulic Summary, Appendix B, and Figure 7.

Channel roughness factors (Manning's “ $n$ ”) used in the hydraulic model were estimated using field inspections at each cross section following the general guidelines described by Arcement and Schneider (1989). Final adjustments to the values were made during the modelling of the reach. Channel " $\mathrm{n}$ " values for the reach ranged from 0.045 to 0.060 , and overbank " $n$ " values ranged from 0.040 to 0.070 .

Normal depth at the exit section (EXITX) was assumed as the starting water surface. This depth was computed by use of the slope-conveyance method outlined in the user's manual for WSPRO (Shearman, 1990). The slope used was $0.0164 \mathrm{ft} / \mathrm{ft}$, which was estimated from surveyed downstream thalweg points.

The surveyed approach section (APTEM) was moved along the approach channel slope $(0.0619 \mathrm{ft} / \mathrm{ft})$ to establish the modelled approach section (APPRO), one bridge length upstream of the upstream face as recommended by Shearman and others (1986). This location also provides a consistent method for determining scour variables. 


\section{Bridge Hydraulics Summary}

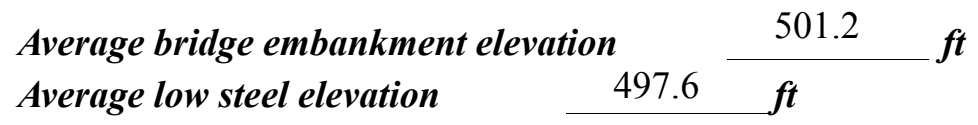

100-year discharge $\quad 1,490 \quad \mathrm{ft}^{3} / \mathrm{s}$

Water-surface elevation in bridge opening $\quad 497.8 \quad f t$

Road overtopping? ___ Yes Discharge over road __ $424 \quad \mathrm{ft}^{3} / \mathrm{s}$

Area of flow in bridge opening $\quad 97 \quad \mathrm{ft}^{2}$

Average velocity in bridge opening $11.0 \quad \mathrm{ft} / \mathrm{s}$

$\begin{array}{lll}\text { Maximum WSPRO tube velocity at bridge } & 12.7 \mathrm{ft} / \mathrm{s}\end{array}$

Water-surface elevation at Approach section with bridge $\quad 501.4$

Water-surface elevation at Approach section without bridge $\quad \overline{499.2}$

Amount of backwater caused by bridge $\quad 2.2$ it

500-year discharge $\quad 2,100 \quad \mathrm{ft}^{3} / \mathrm{s}$

Water-surface elevation in bridge opening $\quad 497.8 \mathrm{ft}$

Road overtopping? ___ Yes Discharge over road __ 1,050 $\mathrm{ft}^{3} / \mathrm{s}$

Area of flow in bridge opening $\quad 97 \quad \mathrm{ft}^{2}$

Average velocity in bridge opening $\quad 10.9 \mathrm{ft} / \mathrm{s}$

Maximum WSPRO tube velocity at bridge 12.6 's

Water-surface elevation at Approach section with bridge $\quad 502.0$

Water-surface elevation at Approach section without bridge $\quad 499.9$

Amount of backwater caused by bridge $2.1, t$

Incipient overtopping discharge $\quad 770 \quad \mathrm{ft}^{3} / \mathrm{s}$

Water-surface elevation in bridge opening $497.8 \quad t$

Area of flow in bridge opening

Average velocity in bridge opening

Maximum WSPRO tube velocity at bridge

$97 \quad \mathrm{ft}^{2}$

2

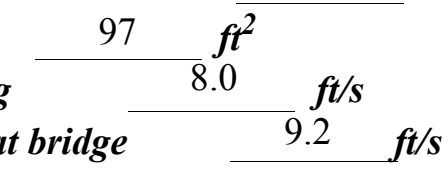

Water-surface elevation at Approach section with bridge

Water-surface elevation at Approach section without bridge

499.5

Amount of backwater caused by bridge

2.0 . $t$

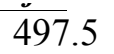




\section{Scour Analysis Summary}

\section{Special Conditions or Assumptions Made in Scour Analysis}

Scour depths were computed using the general guidelines described in Hydraulic Engineering Circular 18 (Richardson and Davis, 1995). Scour depths were calculated assuming an infinite depth of erosive material and a homogeneous particle-size distribution. The results of the 100- and 500-year scour analysis are presented in Tables 1 and 2 and the scour depths are presented graphically in Figure 8.

At this site, the 100- and 500-year discharges resulted in submerged orifice flow, while the incipient roadway-overtopping discharge resulted in unsubmerged orifice flow. Contraction scour at bridges with orifice flow is best estimated by use of the Chang pressureflow scour equation (oral communication, J. Sterling Jones, October 4, 1996). Thus, contraction scour for these discharges was computed by use of the Chang equation (Richardson and Davis, 1995, p. 145-146). The computed streambed armoring depths suggest that armoring will not limit the depth of contraction scour.

For comparison, contraction scour for the discharges resulting in orifice flow was also computed by use of the Laursen clear-water contraction scour equation (Richardson and Davis, 1995, p. 32, equation 20) and the Umbrell pressure-flow equation (Richardson and Davis, 1995, p. 144) and presented in Appendix F. Furthermore, for the discharge resulting in unsubmerged orifice flow, contraction scour was computed by substituting an estimate for the depth of flow at the downstream bridge face in the contraction scour equations. Results with respect to this substitution are provided in Appendix F.

Abutment scour was computed by use of the Froehlich equation (Richardson and Davis, 1995, p. 48, equation 28). Variables for the Froehlich equation include the Froude number of the flow approaching the embankments, the length of the embankment blocking flow, and the depth of flow approaching the embankment less any roadway overtopping. 


\section{Scour Results}

\section{0-yr discharge 500-yr discharge}

Contraction scour:

(Scour depths in feet)

Main channel

Live-bed scour

Clear-water scour

Depth to armoring

Left overbank

Right overbank

Local scour:

Abutment scour

Left abutment

11.7

11.5

9.6

7.0

$1.7-$

$5.7-$

Right abutment

Pier scour

Pier 1

Pier 2

Pier 3

\section{Abutments:}

Left abutment

Right abutment

Piers:

Pier 1

Pier 2

overtopping discharge 


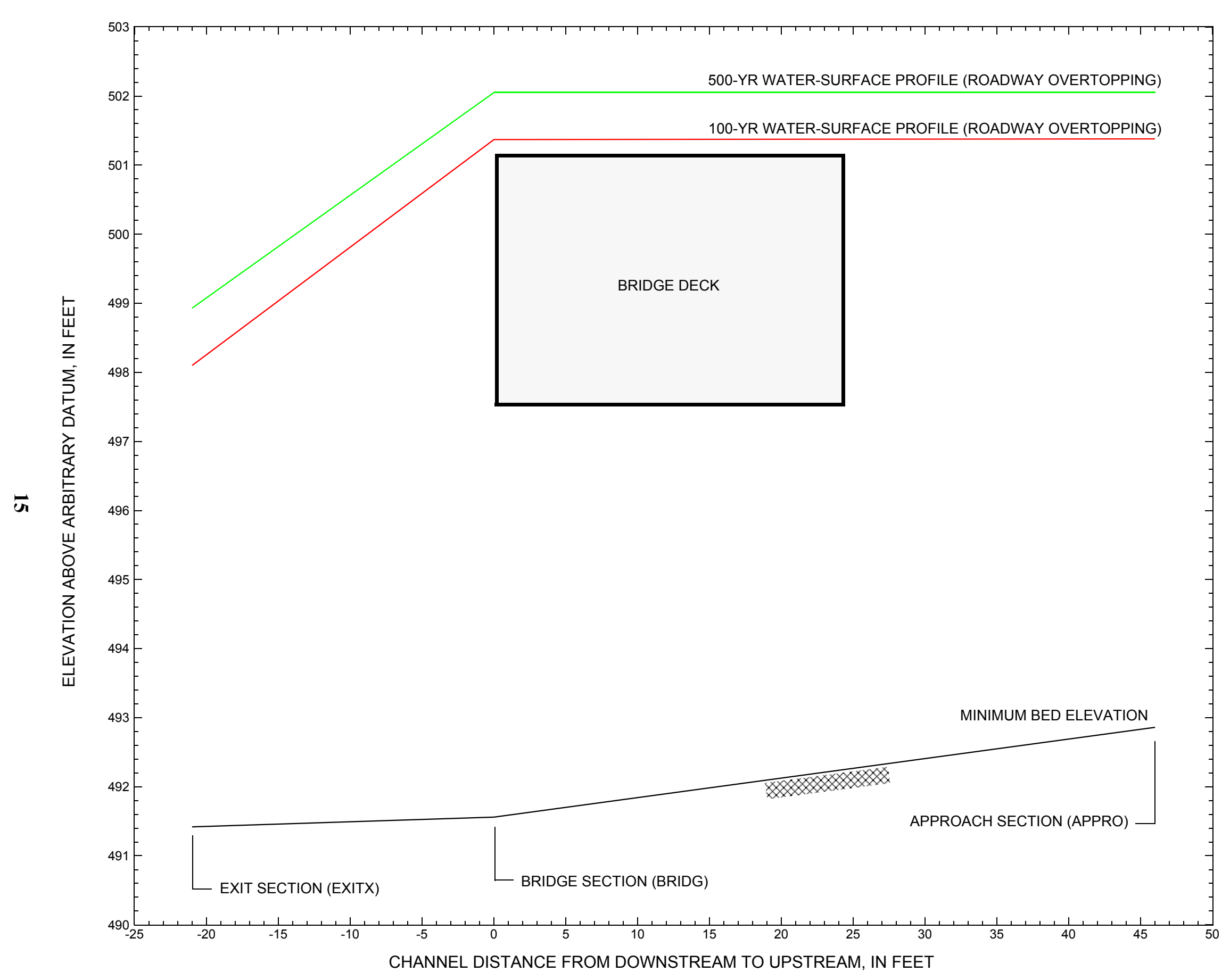

Figure 7. Water-surface profiles for the 100- and 500-yr discharges at structure BURKTH00130033 on Town Highway 13, crossing Roundy Brook, Burke, Vermont. 


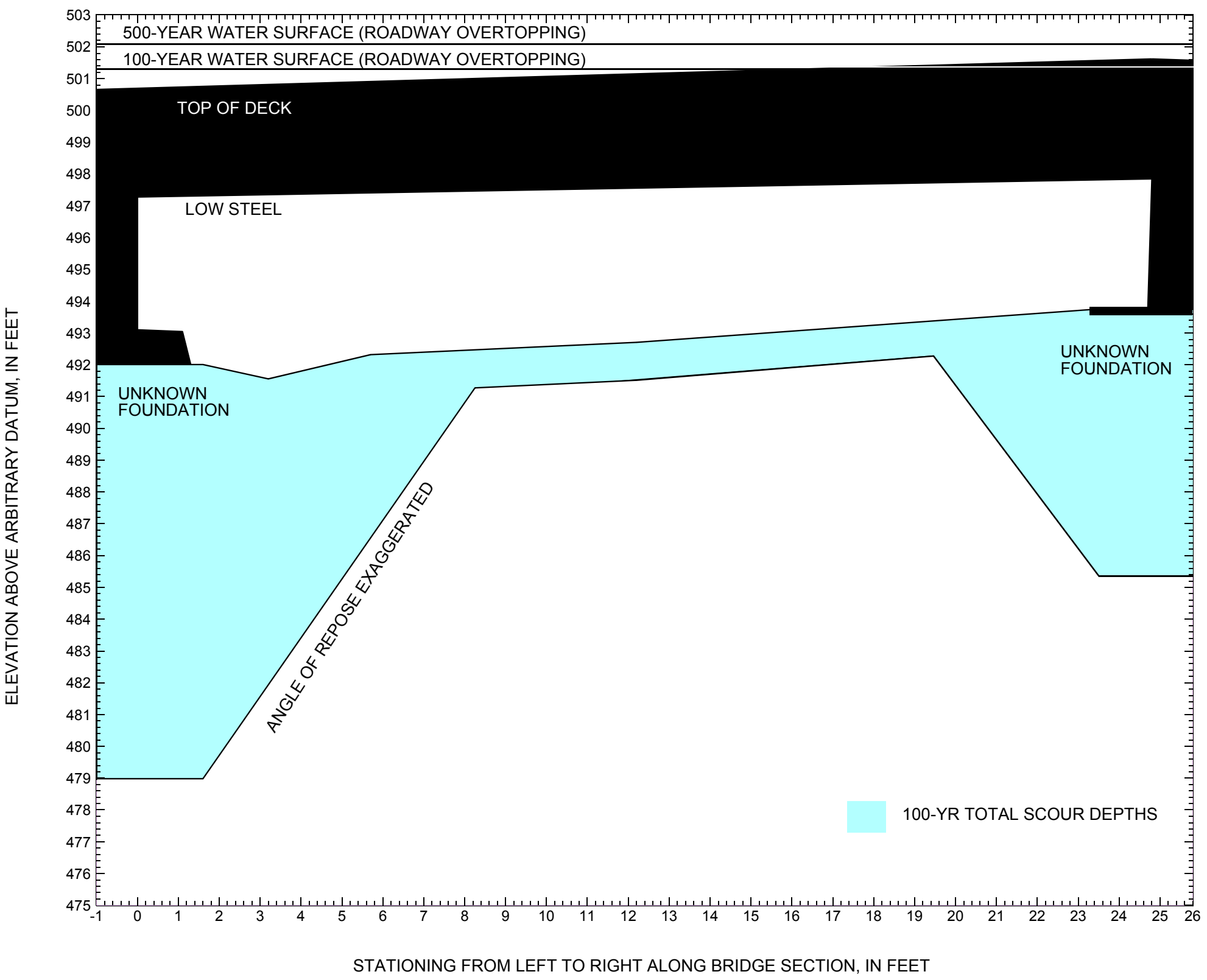

Figure 8. Scour elevations for the 100-yr and 500-yr discharges at structure BURKTH00130033 on Town Highway 13, crossing Roundy Brook, Burke, Vermont. 
Table 1. Remaining footing/pile depth at abutments for the 100-year discharge at structure BURKTH00130033 on Town Highway 13, crossing Roundy Brook, Burke, Vermont.

[VTAOT, Vermont Agency of Transportation; --,no data]

\begin{tabular}{|c|c|c|c|c|c|c|c|c|c|c|c|}
\hline Description & Station ${ }^{1}$ & $\begin{array}{l}\text { VTAOT } \\
\text { minimum } \\
\text { low-chord } \\
\text { elevation } \\
\text { (feet) }\end{array}$ & $\begin{array}{l}\text { Surveyed } \\
\text { minimum } \\
\text { low-chord } \\
\text { elevation }{ }^{2} \\
\text { (feet) }\end{array}$ & $\begin{array}{c}\text { Bottom of } \\
\text { footing/pile } \\
\text { elevation }{ }^{2} \\
\text { (feet) }\end{array}$ & $\begin{array}{c}\text { Channel } \\
\text { elevation at } \\
\text { abutment/ } \\
\text { pier }^{2} \\
\text { (feet) }\end{array}$ & $\begin{array}{l}\text { Contraction } \\
\text { scour depth } \\
\text { (feet) }\end{array}$ & $\begin{array}{l}\text { Abutment } \\
\text { scour } \\
\text { depth } \\
\text { (feet) }\end{array}$ & $\begin{array}{l}\text { Pier } \\
\text { scour } \\
\text { depth } \\
\text { (feet) }\end{array}$ & $\begin{array}{l}\text { Depth of } \\
\text { total scour } \\
\text { (feet) }\end{array}$ & $\begin{array}{c}\text { Elevation of } \\
\text { scour }^{2} \\
\text { (feet) }\end{array}$ & $\begin{array}{c}\text { Remaining } \\
\text { footing/pile } \\
\text { depth } \\
\text { (feet) }\end{array}$ \\
\hline \multicolumn{12}{|c|}{100 -yr. discharge is 1,490 cubic-feet per second } \\
\hline Left abutment & 0.0 & - & 497.3 & - & 492.0 & 1.4 & 11.7 & -- & 13.1 & 478.9 & - \\
\hline Right abutment & 24.8 & - & 497.8 & - & 493.8 & 1.4 & 7.0 & -- & 8.4 & 485.4 & - \\
\hline
\end{tabular}

1.Measured along the face of the most constricting side of the bridge.

2.Arbitrary datum for this study.

Table 2. Remaining footing/pile depth at abutments for the 500-year discharge at structure BURKTH00130033 on Town Highway 13, crossing Roundy Brook, Burke, Vermont.

[VTAOT, Vermont Agency of Transportation; --, no data]

\begin{tabular}{|c|c|c|c|c|c|c|c|c|c|c|c|}
\hline Description & Station $^{1}$ & $\begin{array}{l}\text { VTAOT } \\
\text { minimum } \\
\text { low-chord } \\
\text { elevation } \\
\text { (feet) }\end{array}$ & $\begin{array}{c}\text { Surveyed } \\
\text { minimum } \\
\text { low-chord } \\
\text { elevation } \\
\text { (feet) }\end{array}$ & $\begin{array}{c}\text { Bottom of } \\
\text { footing/pile } \\
\text { elevation } \\
\text { (feet) }\end{array}$ & $\begin{array}{c}\text { Channel } \\
\text { elevation at } \\
\text { abutment/ } \\
\text { pier }^{2} \\
\text { (feet) }\end{array}$ & $\begin{array}{l}\text { Contraction } \\
\text { scour depth } \\
\text { (feet) }\end{array}$ & $\begin{array}{c}\text { Abutment } \\
\text { scour } \\
\text { depth } \\
\text { (feet) }\end{array}$ & $\begin{array}{l}\text { Pier } \\
\text { scour } \\
\text { depth } \\
\text { (feet) }\end{array}$ & $\begin{array}{l}\text { Depth of } \\
\text { total scour } \\
\text { (feet) }\end{array}$ & $\begin{array}{c}\text { Elevation of } \\
\text { scour }^{2} \\
\text { (feet) }\end{array}$ & $\begin{array}{c}\text { Remaining } \\
\text { footing/pile } \\
\text { depth } \\
\text { (feet) }\end{array}$ \\
\hline \multicolumn{12}{|c|}{500 -yr. discharge is 2,100 cubic-feet per second } \\
\hline Left abutment & 0.0 & - & 497.3 & - & 492.0 & 1.2 & 11.5 & -- & 12.7 & 479.3 & - \\
\hline Right abutment & 24.8 & - & 497.8 & - & 493.8 & 1.2 & 1.7 & -- & 2.9 & 490.9 & - \\
\hline
\end{tabular}

1.Measured along the face of the most constricting side of the bridge.

2.Arbitrary datum for this study. 


\section{SELECTED REFERENCES}

Arcement, G.J., Jr., and Schneider, V.R., 1989, Guide for selecting Manning's roughness coefficients for natural channels and flood plains:

U.S. Geological Survey Water-Supply Paper 2339, 38 p.

Barnes, H.H., Jr., 1967, Roughness characteristics of natural channels: U.S. Geological Survey Water-Supply Paper 1849,213 p.

Benson, M. A., 1962, Factors Influencing the Occurrence of Floods in a Humid Region of Diverse Terrain: U.S. Geological Survey WaterSupply Paper 1580-B, 64 p.

Brown, S.A. and Clyde, E.S., 1989, Design of riprap revetment: Federal Highway Administration Hydraulic Engineering Circular No. 11, Publication FHWA-IP-89-016, 156 p.

Federal Emergency Management Agency, 1979, Flood Insurance Study, Town of Burke, Caledonia County, Vermont: Washington, D.C., December 1979.

Federal Highway Administration, 1983, Runoff estimates for small watersheds and development of sound design: Federal Highway Administration Report FHWA-RD-77-158.

Federal Highway Administration, 1993, Stream Stability and Scour at Highway Bridges: Participant Workbook: Federal Highway Administration Report FHWA-HI-91-011.

Froehlich, D.C., 1989, Local scour at bridge abutments in Ports, M.A., ed., Hydraulic Engineering--Proceedings of the 1989 National Conference on Hydraulic Engineering: New York, American Society of Civil Engineers, p. 13-18.

Hayes, D.C.,1993, Site selection and collection of bridge-scour data in Delaware, Maryland, and Virginia: U.S. Geological Survey WaterResources Investigation Report 93-4017, 23 p.

Interagency Advisory Committee on Water Data, 1982, Guidelines for determining flood flow frequency: U.S. Geological Survey, Bulletin 17B of the Hydrology Subcommittee, 190 p.

Johnson, C.G. and Tasker, G.D.,1974, Progress report on flood magnitude and frequency of Vermont streams: U.S. Geological Survey OpenFile Report 74-130, 37 p.

Lagasse, P.F., Schall, J.D., Johnson, F., Richardson, E.V., Chang, F., 1995, Stream Stability at Highway Structures: Federal Highway Administration Hydraulic Engineering Circular No. 20, Publication FHWA-IP-90-014, 144 p.

Laursen, E.M., 1960, Scour at bridge crossings: Journal of the Hydraulics Division, American Society of Civil Engineers, v. 86, no. HY2, p. 39-53.

Potter, W. D., 1957a, Peak rates of runoff in the Adirondack, White Mountains, and Maine woods area, Bureau of Public Roads

Potter, W. D., 1957b, Peak rates of runoff in the New England Hill and Lowland area, Bureau of Public Roads

Richardson, E.V. and Davis, S.R., 1995, Evaluating scour at bridges: Federal Highway Administration Hydraulic Engineering Circular No. 18, Publication FHWA-IP-90-017, 204 p.

Richardson, E.V., Simons, D.B., and Julien, P.Y., 1990, Highways in the river environment: Federal Highway Administration Publication FHWA-HI-90-016.

Ritter, D.F., 1984, Process Geomorphology: W.C. Brown Co., Debuque, Iowa, 603 p.

Shearman, J.O., 1990, User's manual for WSPRO--a computer model for water surface profile computations: Federal Highway Administration Publication FHWA-IP-89-027, 187 p.

Shearman, J.O., Kirby, W.H., Schneider, V.R., and Flippo, H.N., 1986, Bridge waterways analysis model; research report: Federal Highway Administration Publication FHWA-RD-86-108, 112 p.

Talbot, A.N., 1887, The determination of water-way for bridges and culverts.

U.S. Department of Transportation, 1993, Stream stability and scour at highway bridges, Participant Workbook: Federal Highway Administration Publication FHWA HI-91-011.

U.S. Geological Survey, 1988, West Burke, Vermont 7.5 Minute Series quadrangle map: U.S. Geological Survey Topographic Maps, Scale $1: 24,000$. 


\section{APPENDIX A: \\ WSPRO INPUT FILE}




\section{WSPRO INPUT FILE}

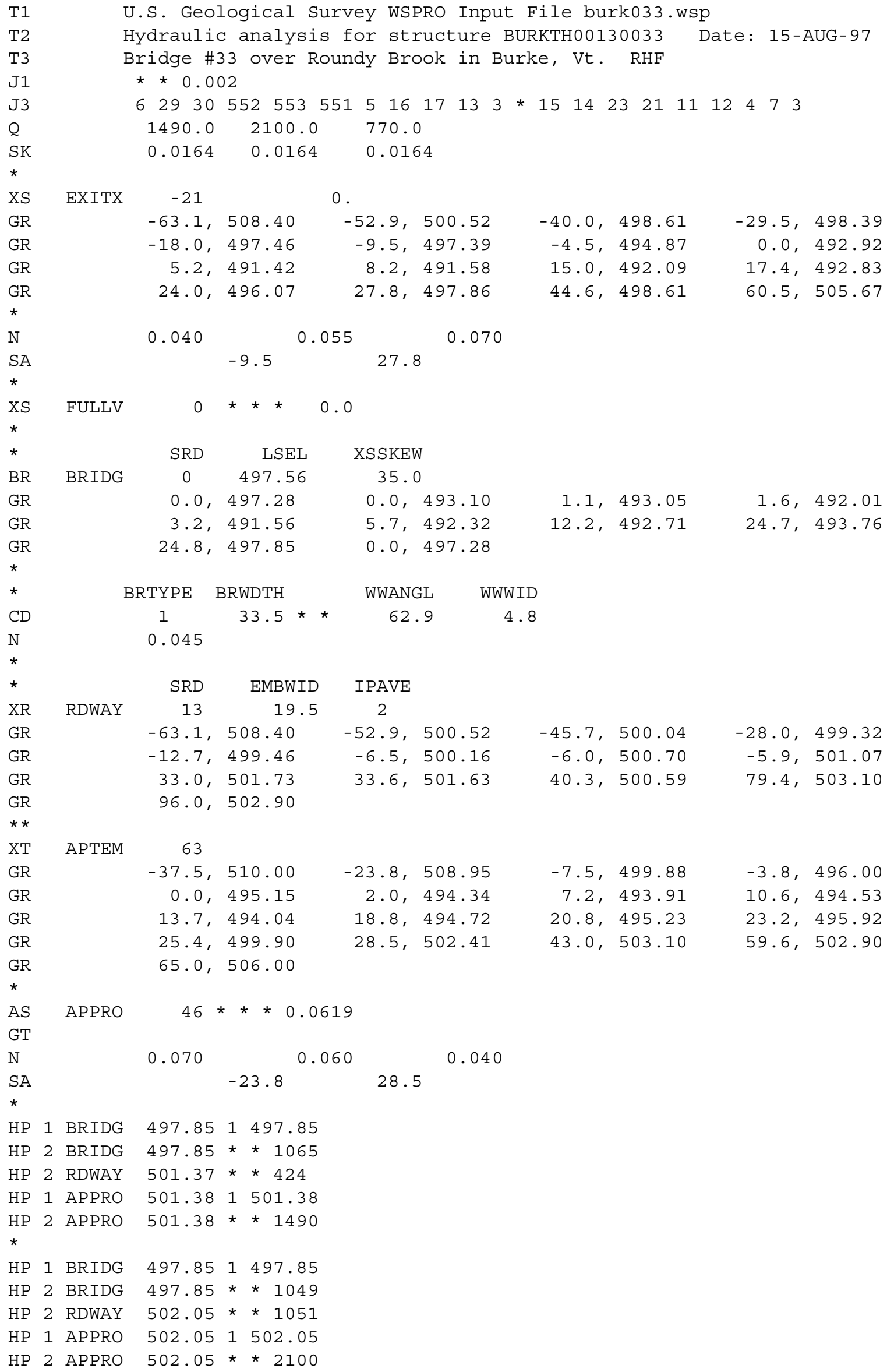




\section{APPENDIX B: \\ WSPRO OUTPUT FILE}




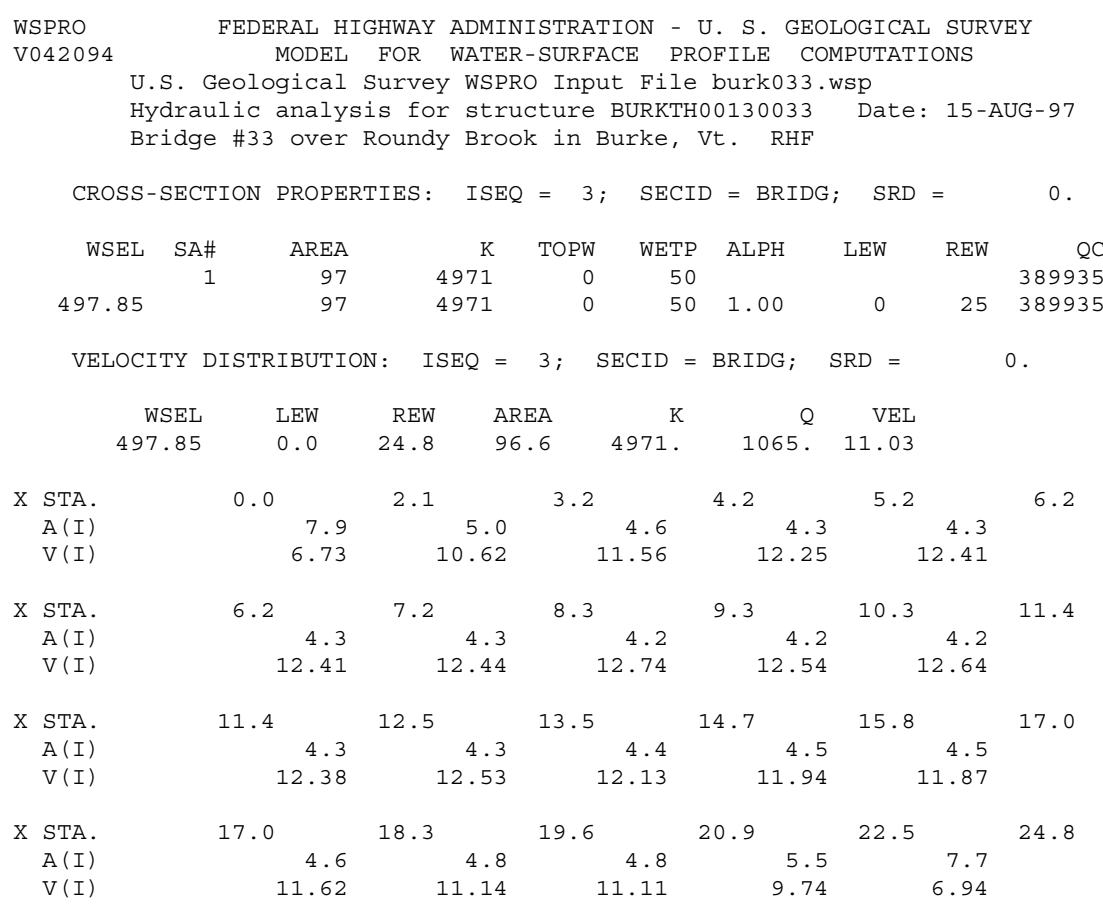

VELOCITY DISTRIBUTION : ISEQ $=4 ;$ SECID $=$ RDWAY $; \quad$ SRD $=$

\begin{tabular}{|c|c|c|c|c|c|c|c|c|c|c|c|}
\hline & & NSEL & LEW & REW & & REA & $\mathrm{K}$ & $Q$ & VEL & & \\
\hline & 50 & 1.37 & 54.0 & 11.8 & & 1.4 & 3950 . & 424. & 5.21 & & \\
\hline $\mathrm{X}$ & STA. & -54.0 & & -47.6 & & -44.0 & -4 & 1.0 & -38.4 & & -36.0 \\
\hline & $A(I)$ & & 5.9 & & 4.7 & & 4.4 & 4.1 & & 4.0 & \\
\hline & $V(I)$ & & 3.57 & & 4.47 & & 4.85 & 5.20 & & 5.27 & \\
\hline $\mathrm{X}$ & STA. & -36.0 & & -33.9 & & -31.8 & -3 & 0.0 & -28.2 & & -26.6 \\
\hline & $A(I)$ & & 3.8 & & 3.7 & & 3.6 & 3.5 & & 3.4 & \\
\hline & $V(I)$ & & 5.62 & & 5.67 & & 5.93 & 6.10 & & 6.18 & \\
\hline $\mathrm{X}$ & STA. & -26.6 & & -24.9 & & -23.2 & -2 & 1.5 & -19.8 & & -18.1 \\
\hline & $A(I)$ & & 3.4 & & 3.4 & & 3.4 & 3.4 & & 3.4 & \\
\hline & $V(I)$ & & 6.20 & & 6.24 & & 6.22 & 6.32 & & 6.25 & \\
\hline $\mathrm{X}$ & STA. & -18.1 & & -16.3 & & -14.5 & -1 & 2.7 & -10.8 & & 11.8 \\
\hline & $A(I)$ & & 3.4 & & 3.5 & & 3.4 & 3.6 & & 9.4 & \\
\hline & $V(I)$ & & 6.16 & & 6.13 & & 6.20 & 5.95 & & 2.27 & \\
\hline & CROSS & -SECTION & PROPER & RTIES: & ISEQ & $2=5 ;$ & SECID & $=A P P R O$ & SRD & $=$ & 46. \\
\hline & WSEL & SA\# & AREA & & K & TOPW & WETP & $\mathrm{ALPH}$ & LEW & REW & QCR \\
\hline & & 2 & 247 & & 3569 & 41 & 47 & & & & 3450 \\
\hline & & 3 & 0 & & 0 & 0 & 0 & & & & 0 \\
\hline & 501.38 & & 247 & & 3569 & 41 & 47 & 1.00 & -11 & 29 & 3430 \\
\hline
\end{tabular}

VELOCITY DISTRIBUTION: ISEQ $=5 ;$ SECID $=$ APPRO; $\operatorname{SRD}=46$.

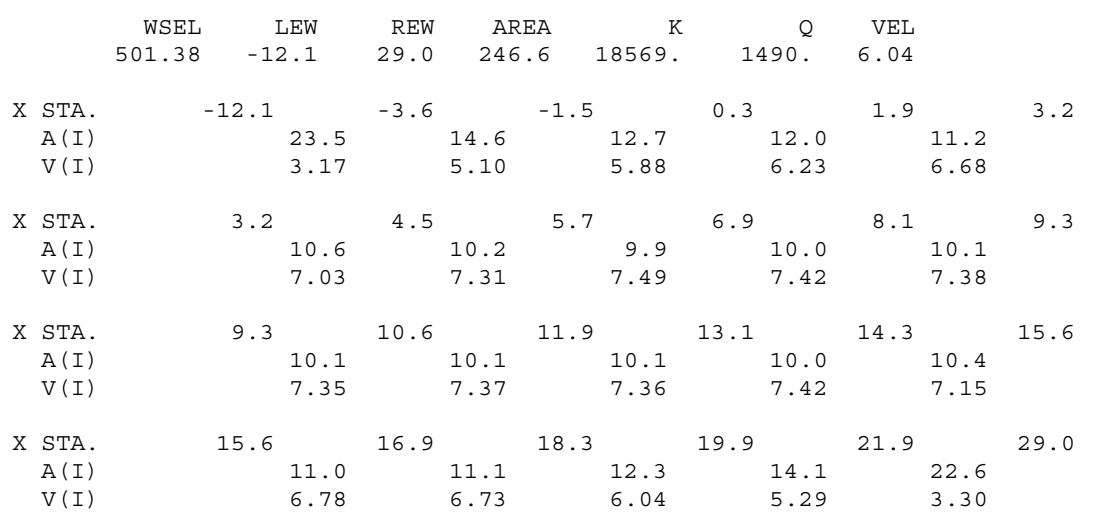


WSPRO OUTPUT FILE (continued)

\begin{tabular}{|c|c|c|c|c|c|c|c|c|c|c|c|}
\hline \multicolumn{9}{|c|}{$\begin{array}{l}\text { U.S. Geological Survey WSPRO Input File burk033.w } \\
\text { Hydraulic analysis for structure BURKTH00130033 } \\
\text { Bridge } \# 33 \text { over Roundy Brook in Burke Vt. RHF }\end{array}$} & \multicolumn{3}{|c|}{ Date: 15-AUG-97 } \\
\hline \multicolumn{3}{|c|}{ CROSS-SECTION } & \multicolumn{2}{|c|}{ PROPERTIES: } & ISEQ & $=3$ & SEC & $I D=B R I D G ;$ & SRD & $=$ & 0 . \\
\hline \multirow{2}{*}{\multicolumn{2}{|c|}{ WSEL }} & A\#\# & AREA & & K & TOPW & WET & ALPH & LEW & REW & $\mathrm{QCR}$ \\
\hline & & 1 & 97 & & 4971 & & 5 & 0 & & & 3899352 \\
\hline \multicolumn{2}{|r|}{497.85} & & 97 & & 4971 & & 5 & 1.00 & 0 & 25 & 3899352 \\
\hline & VELOCITY & DISTH & 'RIBUTIO & & ISEQ = & $3 ;$ & SECID & $=$ BRIDG; & $\mathrm{SRD}=$ & & 0 . \\
\hline \multicolumn{3}{|c|}{ WSEL } & LEW & REW & $\mathrm{AR}$ & EA & $\mathrm{K}$ & Q & VEL & & \\
\hline \multicolumn{3}{|c|}{497.85} & 0.0 & 24.8 & 96 & .6 & 4971. & 1049 . & 10.86 & & \\
\hline \multirow[t]{3}{*}{$\mathrm{X}$} & STA. & 0. & & 2.1 & & 3.2 & & 4.2 & 5.2 & & 6.2 \\
\hline & $A(I)$ & & 7.9 & & 5.0 & & 4.6 & 4.3 & & 4.3 & \\
\hline & $V(I)$ & & 6.62 & & 10.46 & & 11.39 & 12.07 & & 12.23 & \\
\hline \multirow[t]{3}{*}{$\mathrm{x}$} & STA. & 6.2 & & 7.2 & & 8.3 & & 9.3 & 10.3 & & 11.4 \\
\hline & $A(I)$ & & 4.3 & & 4.3 & & 4.2 & 4.2 & & 4.2 & \\
\hline & $V(I)$ & & 12.22 & & 12.25 & & 12.55 & 12.35 & & 12.45 & \\
\hline \multirow[t]{3}{*}{$\mathrm{x}$} & STA. & 11.4 & & 12.5 & & 13.5 & & 14.7 & 15.8 & & 17.0 \\
\hline & $A(I)$ & & 4.3 & & 4.3 & & 4.4 & 4.5 & & 4.5 & \\
\hline & $V(I)$ & & 12.19 & & 12.34 & & 11.95 & 11.76 & & 11.69 & \\
\hline & STA. & 17. & & 18.3 & & 19.6 & & 20.9 & 22.5 & & 24.8 \\
\hline & $A(I)$ & & 4.6 & & 4.8 & & 4.8 & 5.5 & & 7.7 & \\
\hline & $V(I)$ & & 11.45 & & 10.97 & & 10.94 & 9.60 & & 6.83 & \\
\hline & VELOCITY & DISTF & RIBUTIO & & ISEQ = & $4 ;$ & SECID & $=$ RDWAY; & $\mathrm{SRD}=$ & & 13. \\
\hline \multirow{2}{*}{$\mathrm{x}$} & WSEL & & LEW & REW & $\mathrm{AR}$ & EA & K & Q & VEL & & \\
\hline & 502.05 & & 54.9 & 63.0 & 160 & .1 & 7882 . & 1051. & 6.56 & & \\
\hline \multirow[t]{3}{*}{$\mathrm{x}$} & STA. & -54. & & $-48 \cdot 3$ & & -44.7 & & -41.5 & -38.7 & & -36.0 \\
\hline & $A(I)$ & & 9.2 & & 7.1 & & 6.7 & 6.4 & & 6.3 & \\
\hline & $V(I)$ & & 5.71 & & 7.36 & & 7.86 & 8.24 & & 8.34 & \\
\hline \multirow[t]{3}{*}{$\mathrm{x}$} & STA. & -36.0 & & -33.5 & & -31.2 & & -29.1 & -27.0 & & -24.9 \\
\hline & $A(I)$ & & 6.0 & & 5.8 & & 5.7 & 5.6 & & 5.6 & \\
\hline & $V(I)$ & & 8.70 & & 9.03 & & 9.18 & 9.35 & & 9.37 & \\
\hline \multirow[t]{3}{*}{$\mathrm{x}$} & STA. & -24.9 & & -22.9 & & -20.8 & & -18.7 & -16.6 & & -14.4 \\
\hline & $\mathrm{A}(\mathrm{I})$ & & 5.6 & & 5.5 & & 5.5 & 5.7 & & 5.6 & \\
\hline & $V(I)$ & & 9.47 & & 9.53 & & 9.49 & 9.24 & & 9.42 & \\
\hline $\mathrm{X}$ & STA. & -14.4 & & -12.3 & & -9.8 & & -0.4 & 35.5 & & 63.0 \\
\hline & $A(I)$ & & 5.6 & & 6.0 & & 12.9 & 21.5 & & 21.8 & \\
\hline & $V(I)$ & & 9.31 & & 8.80 & & 4.08 & 2.45 & & 2.41 & \\
\hline & CROSS-SEC & CTION & PROPER & TIES : & ISEQ & $=5$ & SEC & $I D=A P P R O ;$ & SRD & $=$ & 46. \\
\hline & WSEL & A\# & AREA & & K & TOPW & WET & ALPH & LEW & REW & QCR \\
\hline & & 2 & 274 & & 21735 & 42 & 4 & 8 & & & 3986 \\
\hline & & 3 & 7 & & 90 & 31 & 3 & 2 & & & 18 \\
\hline & 502.05 & & 281 & & 21825 & 73 & 8 & 1.04 & -12 & 60 & 3067 \\
\hline & VELOCITY & DISTR & RIBUTIO & & ISEQ = & $5 ;$ & SECID & $=\mathrm{APPRO} ;$ & $\mathrm{SRD}=$ & & 46. \\
\hline & WSEL & & LEW & REW & $\mathrm{AR}$ & $E A$ & $\mathrm{~K}$ & Q & VEL & & \\
\hline & 502.05 & & 13.3 & 60.0 & 281 & .0 & 21825 . & 2100 & 7.47 & & \\
\hline $\mathrm{x}$ & STA. & $-13 \cdot 3$ & & -4.0 & & -1.7 & & 0.1 & 1.7 & & 3.1 \\
\hline & $A(I)$ & & 26.8 & & 17.0 & & 14.3 & 13.4 & & 12.2 & \\
\hline & $V(I)$ & & 3.92 & & 6.19 & & 7.35 & 7.83 & & 8.57 & \\
\hline $\mathrm{X}$ & STA. & 3.1 & & 4.5 & & 5.8 & & 7.0 & 8.2 & & 9.5 \\
\hline & $A(I)$ & & 12.0 & & 11.7 & & 11.2 & 11.2 & & 11.3 & \\
\hline & $V(I)$ & & 8.78 & & 9.00 & & 9.41 & 9.35 & & 9.29 & \\
\hline $\mathrm{X}$ & STA. & 9.5 & & 10.8 & & 12.1 & & 13.3 & 14.6 & & 15.9 \\
\hline & $A(I)$ & & 11.2 & & 11.3 & & 11.3 & 11.1 & & 11.5 & \\
\hline & $\mathrm{V}(\mathrm{I})$ & & 9.35 & & 9.30 & & 9.31 & 9.45 & & 9.13 & \\
\hline $\mathrm{X}$ & STA. & 15.9 & & 17.3 & & 18.8 & & 20.4 & 22.4 & & 60.0 \\
\hline & $A(I)$ & & 12.1 & & 12.6 & & 13.2 & 15.5 & & 30.1 & \\
\hline & $V(I)$ & & 8.64 & & 8.33 & & 7.93 & 6.76 & & 3.49 & \\
\hline
\end{tabular}


WSPRO OUTPUT FILE (continued)

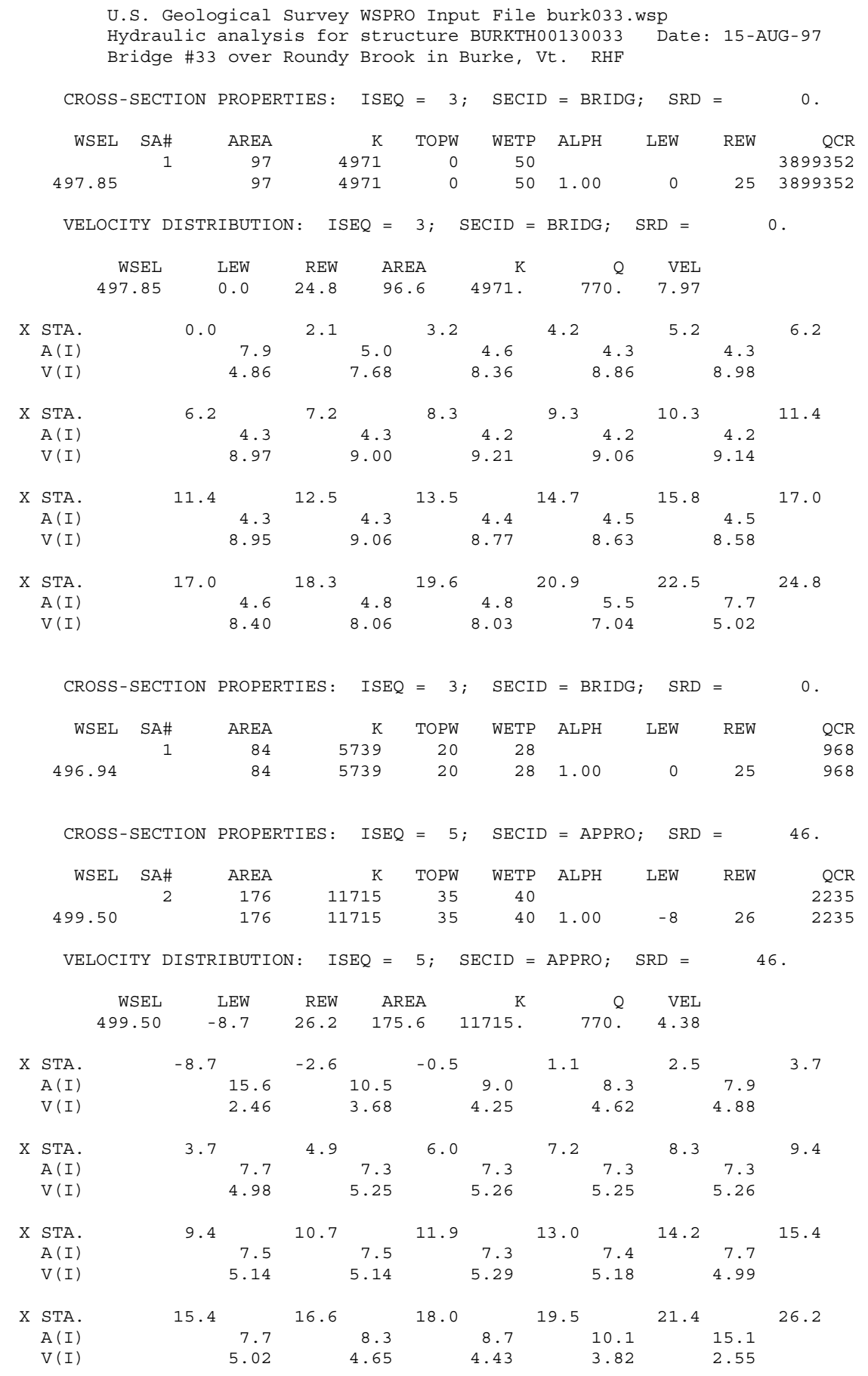


WSPRO OUTPUT FILE (continued)

WSPRO FEDERAL HIGHWAY ADMINISTRATION - U. S. GEOLOGICAL SURVEY

V042094 MODEL FOR WATER-SURFACE PROFILE COMPUTATIONS

U.S. Geological Survey WSPRO Input File burk033.wsp

Hydraulic analysis for structure BURKTH00130033 Date: 15-AUG-97

Bridge \#33 over Roundy Brook in Burke, Vt. RHF

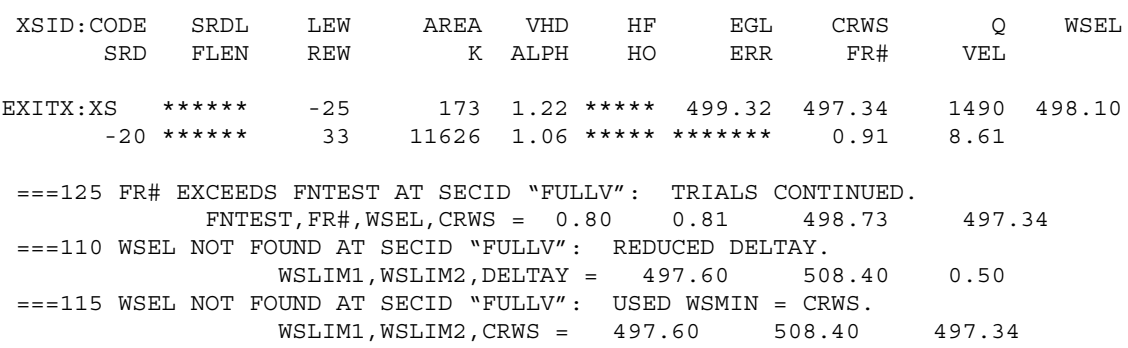

FIRST USER DEFINED TABLE.

\begin{tabular}{|c|c|c|c|c|c|c|c|c|}
\hline XSID: CODE & SRD & LEW & REW & Q & $\mathrm{K}$ & AREA & VEL & WSEL \\
\hline EXITX:XS & -21 & -26 & 33. & 1490. & 11626 . & 173. & 8.61 & 498.10 \\
\hline FULLV : FV & 0 . & -41 & 45. & 1490. & 15276 . & 221 . & 6.73 & 498.76 \\
\hline BRIDG : BR & 0 . & 0 & 25. & 1065. & 4971 . & 97. & 11.03 & 497.85 \\
\hline RDWAY : RG & $13 . *$ & $\star \star \star \star \star \star *$ & 424. & 424 & 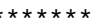 & 0 . & 2.00 & 501.37 \\
\hline APPRO: AS & 46. & -12 & 29. & 1490. & 18561. & 247 . & 6.04 & 501.38 \\
\hline
\end{tabular}

SECOND USER DEFINED TABLE.

$\begin{array}{lcrrrrrrrr}\text { XSID : CODE } & \text { CRWS } & \text { FR\# } & \text { YMIN } & \text { YMAX } & \text { HF } & \text { HO } & \text { VHD } & \text { EGL } & \text { WSEL } \\ \text { EXITX:XS } & 497.34 & 0.91 & 491.42 & 508.40 * * * * * * * * * * & 1.22 & 499.32 & 498.10 \\ \text { FULLV : FV } & 497.34 & 0.80 & 491.42 & 508.40 & 0.26 & 0.00 & 0.82 & 499.58 & 498.76 \\ \text { BRIDG : BR } & 497.22 & 0.99 & 491.56 & 497.85 * * * * * * * * * * & 1.89 & 499.74 & 497.85 \\ \text { RDWAY:RG } & * * * * * * * * * * * * * * * & 499.32 & 510.00 & 0.17 * * * * * * & 0.57 & 501.78 & 501.37 \\ \text { APPRO:AS } & 498.12 & 0.43 & 492.86 & 508.95 & 0.23 & 0.00 & 0.57 & 501.95 & 501.38\end{array}$


WSPRO OUTPUT FILE (continued)

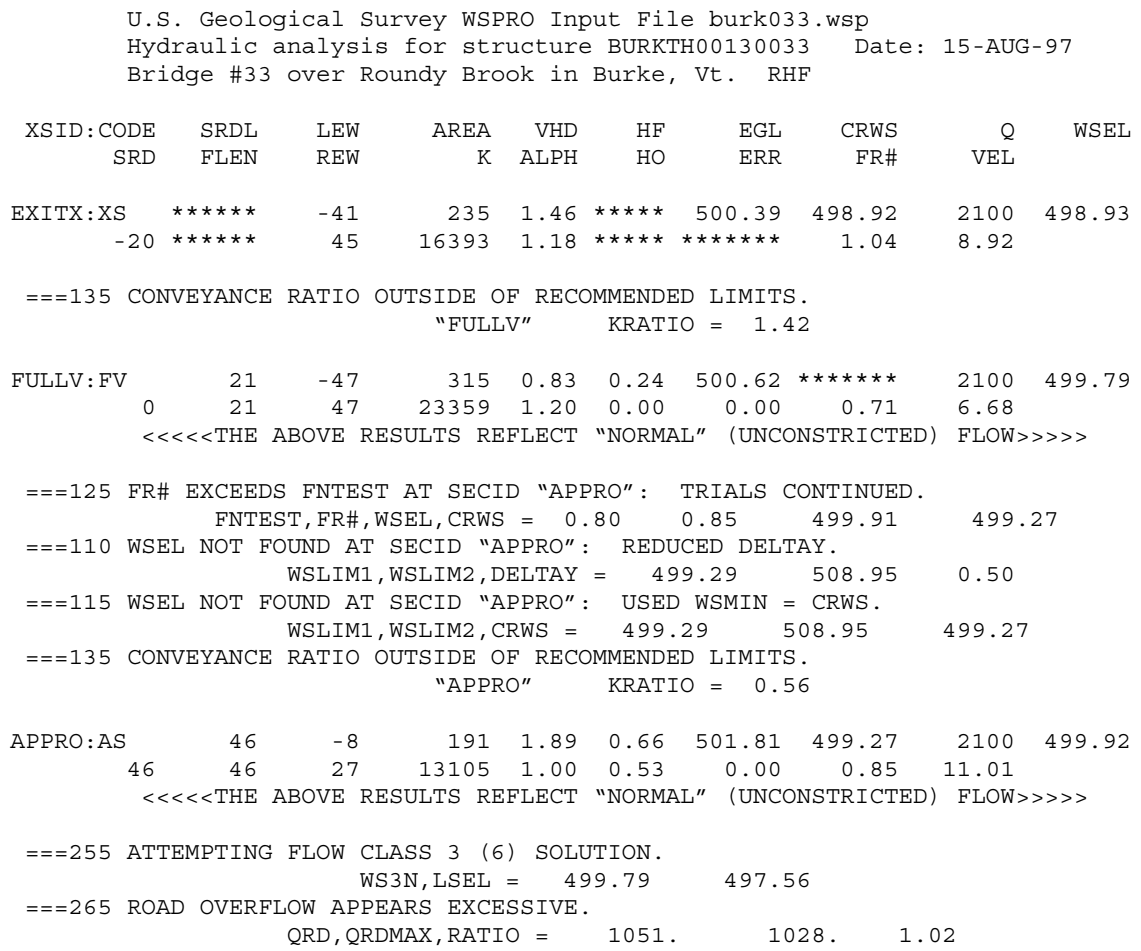

FIRST USER DEFINED TABLE.

$\begin{array}{lrrrrrrrr}\text { XSID : CODE } & \text { SRD } & \text { LEW } & \text { REW } & \text { Q } & \text { K } & \text { AREA } & \text { VEL } & \text { WSEL } \\ \text { EXITX : XS } & -21 . & -42 . & 45 . & 2100 . & 16393 . & 235 . & 8.92 & 498.93 \\ \text { FULLV : FV } & 0 . & -48 . & 47 . & 2100 . & 23359 . & 315 . & 6.68 & 499.79 \\ \text { BRIDG : BR } & 0 . & 0 . & 25 . & 1049 . & 4971 . & 97 . & 10.87 & 497.85 \\ \text { RDWAY : RG } & 13 . * * \star * \star * * & 824 . & 1051 . * \star * \star * \star * \star * & 0 . & 2.00 & 502.05 \\ \text { APPRO : AS } & 46 . & -13 . & 60 . & 2100 . & 21844 . & 281 . & 7.47 & 502.05\end{array}$

SECOND USER DEFINED TABLE.

\begin{tabular}{|c|c|c|c|c|c|c|c|c|c|}
\hline XSID : CODE & CRWS & FR\# & YMIN & YMAX & $\mathrm{HF}$ & $\mathrm{HO}$ & VHD & EGL & WSEI \\
\hline EXITX:XS & 498.92 & 1.04 & 491.42 & 508.40 * & 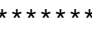 & $\star \star \star \star \star *$ & 1.46 & 500.39 & 498. \\
\hline FULLV : FV & $\star * \star * \star * \star * *$ & 0.71 & 491.42 & 508.40 & 0.24 & 0.00 & 0.83 & 500.62 & 499 \\
\hline BRIDG : BR & 497.18 & 0.97 & 491.56 & $497.85 *$ & 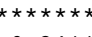 & $\star \star \star \star \star *$ & 1.84 & 499.69 & 497.8 \\
\hline RDWAY : RG & 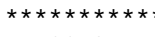 & $\star \star \star \star \star *$ & 499.32 & 508.40 & $0.24 * *$ & $\star \star \star \star \star *$ & 0.90 & 502.71 & 502 . \\
\hline APPRO: AS & 499.27 & 0.68 & 492.86 & 508.95 & 0.30 & 0.00 & 0.90 & 502.95 & 502. \\
\hline
\end{tabular}


WSPRO OUTPUT FILE (continued)

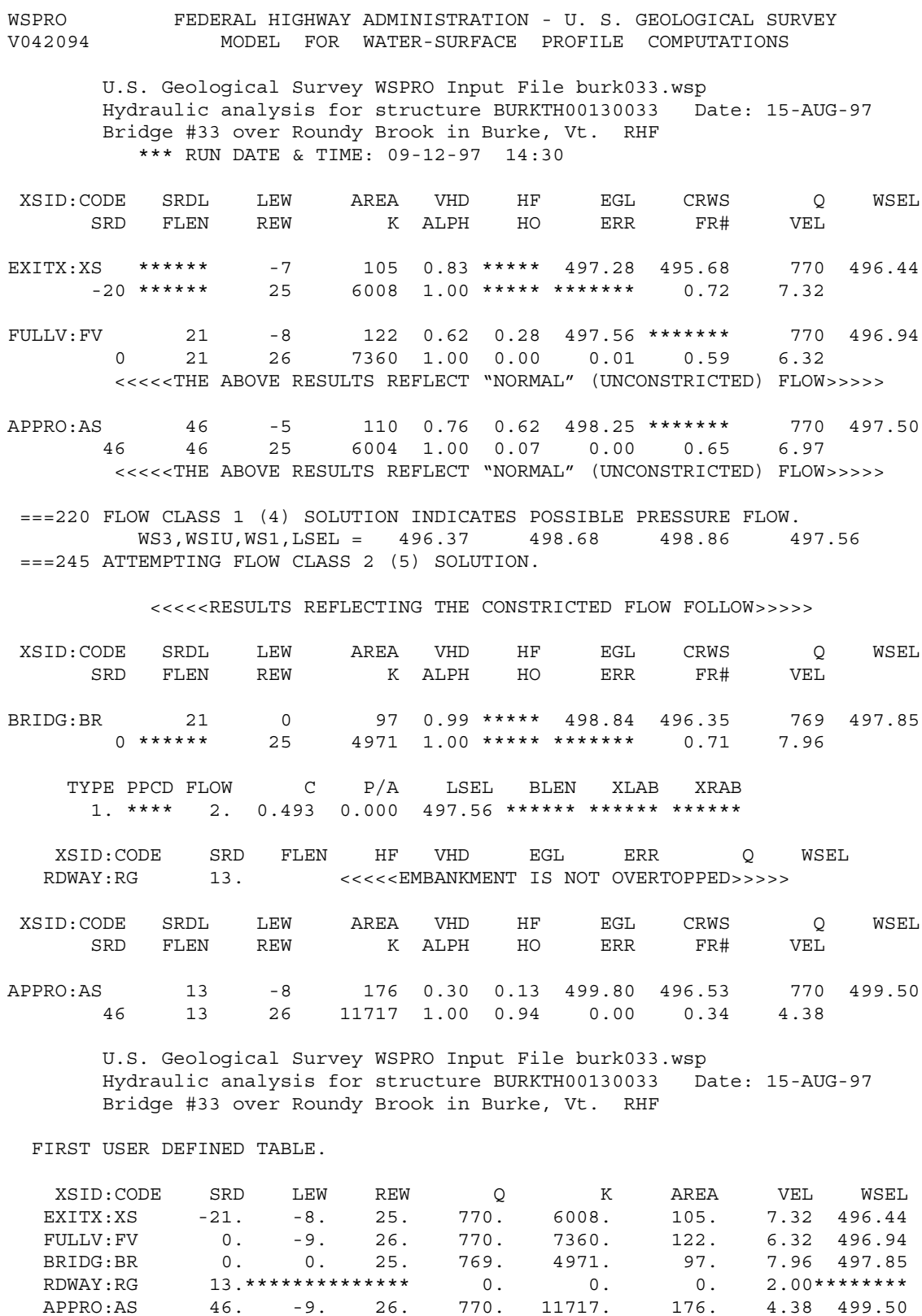

SECOND USER DEFINED TABLE.

$\begin{array}{lcrrrrrrrr}\text { XSID:CODE } & \text { CRWS } & \text { FR\# } & \text { YMIN } & \text { YMAX } & \text { HF } & \text { HO } & \text { VHD } & \text { EGL } & \text { WSEL } \\ \text { EXITX:XS } & 495.68 & 0.72 & 491.42 & 508.40 * * * * * * * * * * * & 0.83 & 497.28 & 496.44 \\ \text { FULLV:FV } & * * * * * * * * & 0.59 & 491.42 & 508.40 & 0.28 & 0.00 & 0.62 & 497.56 & 496.94 \\ \text { BRIDG: BR } & 496.35 & 0.71 & 491.56 & 497.85 * * * * * * * * * * & 0.99 & 498.84 & 497.85 \\ \text { RDWAY:RG } & * * * * * * * * * * * * * * * & 499.32 & 508.40 * * * * * * * * * * * & 0.30 & 499.68 * * * * * * * \\ \text { APPRO:AS } & 496.53 & 0.34 & 492.86 & 508.95 & 0.13 & 0.94 & 0.30 & 499.80 & 499.50 \\ \text { ER } & & & & & & & & & \end{array}$




\section{APPENDIX C:}

\section{BED-MATERIAL PARTICLE-SIZE DISTRIBUTION}




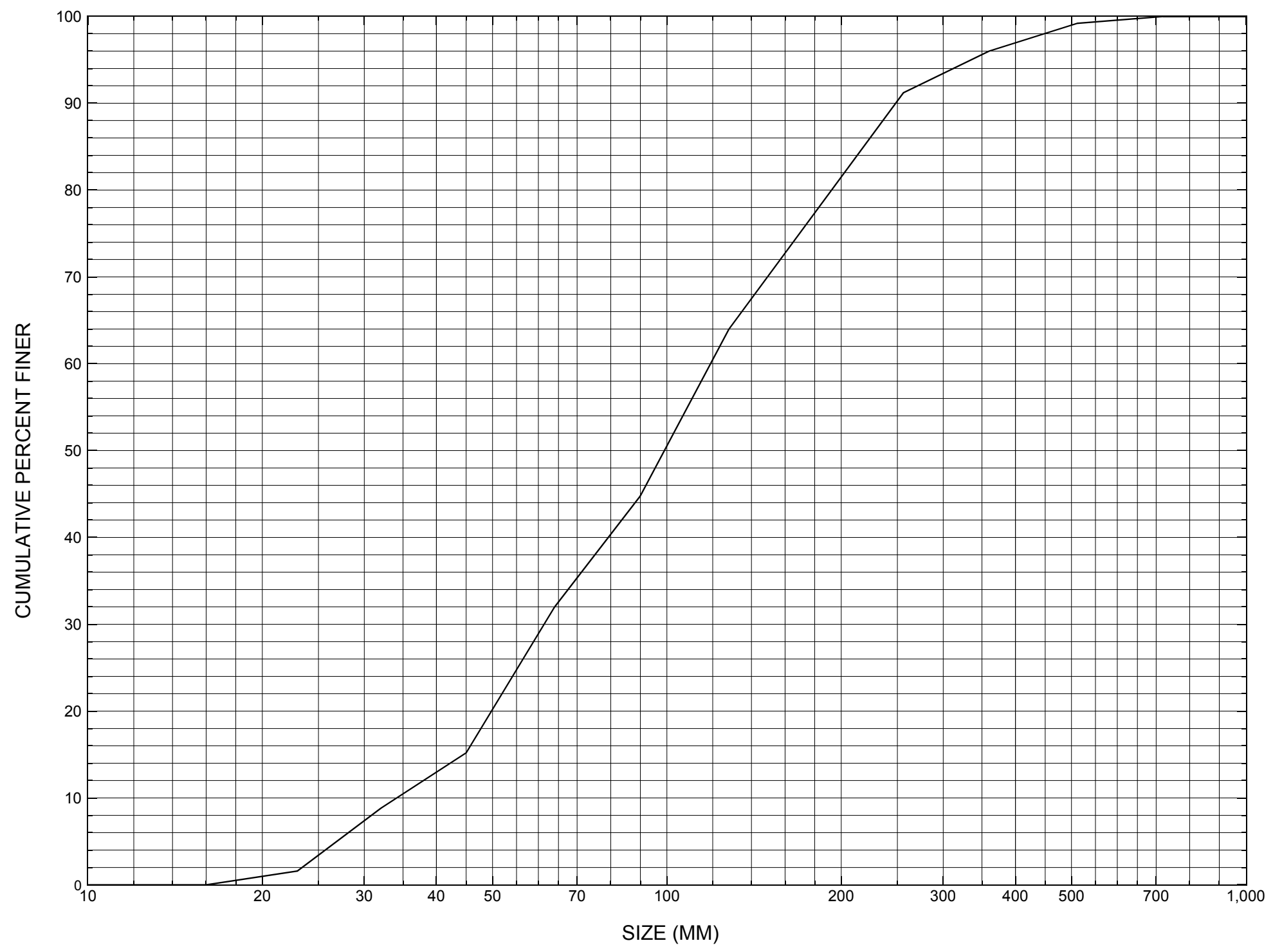

Appendix C. Bed material particle-size distribution for a pebble count in the channel approach of structure BURKTH00130033, in Burke, Vermont. 


\section{APPENDIX D: \\ HISTORICAL DATA FORM}




\section{Structure Number BURKTH00130033}

\section{General Location Descriptive}

Data collected by (First Initial, Full last name) $\mathbf{E}$. BOEHMLER

Date $(M M / D D / Y Y) \_\mathbf{0 3} / \underline{24} / \underline{95}$

Highway District Number (I - 2; nn) $\mathbf{0 7}$

Town (FIPS place code; I - 4; nnnnn) $\mathbf{1 0 4 5 0}$

Waterway (I - 6) ROUNDY BROOK

Route Number TH013

Topographic Map West Burke

Latitude (I - 16; nnnn.n) $4 \mathbf{4 3 7 7}$
County (FIPS county code; I - 3; nnn)

Mile marker (I - 11; nnn.nnn) $\mathbf{0 0 0 0 0 0}$

Road Name (I - 7): -

Vicinity (I - 9) 0.6 MI JCT TH 13 + TH 29

Hydrologic Unit Code: $\mathbf{0 1 0 8 0 1 0 2}$

Longitude (i - 17; nnnnn.n) $\mathbf{7 1 5 6 6}$

\section{Select Federal Inventory Codes}

FHWA Structure Number (I - 8) $\mathbf{1 0 0 3 0 2 0 0 3 3 0 3 0 2}$

Maintenance responsibility $(I-21 ; n n) \quad \mathbf{0 3}$

Year built (I - 27; YYYY) 1928

Average daily traffic, ADT (I - 29; nnnnnn) 000100

Year of ADT (I - 30; YY) $\mathbf{9 2}$

Opening skew to Roadway $(I-34 ; n n) \quad 35$

Operational status $(I-41 ; X) \quad \mathbf{A}$

Structure type (I - 43; nnn) $\mathbf{3 0 2}$

Approach span structure type $(I-44 ; n n n) \quad \mathbf{0 0 0}$

Number of spans (I - 45; nnn) $\mathbf{0 0 1}$

Number of approach spans (I - 46; nnnn) $\mathbf{0 0 0 0}$

Comments:

The structural inspection report of 10/31/94 indicates that the structure is a steel stringer type bridge with a concrete deck. The abutment walls and wingwalls are concrete and reportedly have a few fine cracks, small leaks and spalls overall. The left abutment and its upstream wingwall have a couple of deeper spalls along the base of the wall. The left abutment footing is exposed and its concrete is spalled with small voided areas along the bottom at its upstream end. The right abutment has a 1/8" vertical crack just left of the centerline of the roadway. A small section of the right abutment footing is noted as exposed along the upstream end and along the upstream wingwall. A low, coarse gravel point bar (Continued, page 33) 


\section{Bridge Hydrologic Data}

Is there hydrologic data available? $\underline{\mathbf{N}}$ if No, type ctrl-n $h \quad$ VTAOT Drainage area $\left(m i^{2}\right)$ : -

Terrain character:

Stream character \& type: -

Streambed material:

Discharge Data (cfs):

$$
\begin{aligned}
& Q_{2.33}- \\
& Q_{50}-
\end{aligned}
$$

Record flood date $(M M / D D / Y Y)$ :

Estimated Discharge (cfs): Ice conditions (Heavy, Moderate, Light) : -

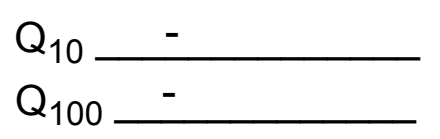

$$
\begin{aligned}
& Q_{25}- \\
& Q_{500}-
\end{aligned}
$$

Water surface elevation $(f t):-$

The stage increases to maximum highwater elevation (Rapidly, Not rapidly):

The stream response is (Flashy, Not flashy):

Describe any significant site conditions upstream or downstream that may influence the stream's stage: -

Watershed storage area (in percent): _ _ \%

The watershed storage area is: - (1-mainly at the headwaters; 2- uniformly distributed; 3-immediatly upstream oi the site)

Water Surface Elevation Estimates for Existing Structure:

\begin{tabular}{|l|l|l|l|l|l|}
\hline Peak discharge frequency & $Q_{2.33}$ & $Q_{10}$ & $Q_{25}$ & $Q_{50}$ & $Q_{100}$ \\
Water surface elevation (ft)) & - & - & - & - & - \\
Velocity (ft/sec) & - & - & - & - & - \\
\hline
\end{tabular}

Long term stream bed changes: -

Is the roadway overtopped below the $\mathrm{Q}_{100}$ ? (Yes, No, Unknown): $\mathbf{U}$ Frequency: Relief Elevation (ft): Discharge over roadway at $Q_{100}\left(f^{3} / \mathrm{sec}\right)$ :

Are there other structures nearby? (Yes, No, Unknown): $\underline{\mathbf{U}}$ Upstream distance (miles): Town: If No or Unknown, type ctrl-n os Highway No. : Structure No. : Year Built:

Clear span (ft): Clear Height $(f t)$ : Full Waterway $\left(f^{2}\right)$ : 
Downstream distance (miles): Town: Year Built:

Highway No. : Structure No. : Structure Type:

Clear span $(f t):$ Clear Height $(f t)$ : Full Waterway $\left(f^{2}\right)$ :

Comments:

is reported in front of the right abutment and blocks half of the channel. Bedrock is noted as outcropped in the upstream channel. Boulders (riprap) also are evident along the up- and downstream banks. The report indicates the channel has a poor alignment with the bridge opening, flowing around a 90 degree bend in order to proceed through the bridge. Debris accumulation is reported as minor.

\section{USGS Watershed Data}

Watershed Hydrographic Data

Drainage area $(D A)$

Watershed storage (ST)

Bridge site elevation

Main channel length

1040
$\mathrm{mi}^{2}$ ) 8.86 $10 \%$ channel length elevation $\mathbf{1 1 7 0}$

Main channel slope (S) 93.29 $\mathrm{ft} / \mathrm{mi}$

Watershed Precipitation Data

Average site precipitation in Average headwater precipitation in

Maximum 2yr-24hr precipitation event $(124,2)$ in

Average seasonal snowfall (Sn) $\mathrm{ft}$ 


\section{Bridge Plan Data}

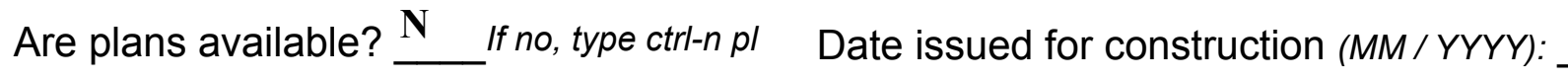

Project Number

Minimum channel bed elevation:

Low superstructure elevation: USLAB DSLAB USRAB DSRAB Benchmark location description:

NO BENCHMARK INFORMATION

Reference Point (MSL, Arbitrary, Other): Datum (NAD27, NAD83, Other):

Foundation Type: 4

If 1: Footing Thickness

If 2: Pile Type: (1-Wood; 2-S

(1-

(1-Spreadfooting; 2-Pile; 3- Gravity; 4-Unknown)

Footing bottom elevation:

If 3 : Footing bottom elevation:
Is boring information available?

Foundation Material Type: $\mathbf{3}$

Briefly describe material at foundation bottom elevation or around piles:

NO FOUNDATION MATERIAL INFORMATION

Comments:

NO PLANS. 


\section{Cross-sectional Data}

Is cross-sectional data available? $\underline{\mathbf{Y}}$ If no, type ctrl-n xs

Source (FEMA, VTAOT, Other)? VTAOT

Comments: This cross section is along the upstream face. The low chord elevations are from the survey log completed for this report on $\mathbf{8 / 8} / \mathbf{9 5}$. The low chord to bed length data is from the sketch attached to an bridge inspection report dated 10/31/94. The sketch was completed on 10/28/92.

\begin{tabular}{|l|l|l|l|l|l|l|l|l|l|l|l|}
\hline Station & $\mathbf{0}$ & 2 & $\mathbf{1 3 . 3}$ & $\mathbf{2 2 . 9}$ & - & - & - & - & - & - & - \\
\hline Feature & LAB & - & - & RAB & - & - & - & - & - & - & - \\
\hline $\begin{array}{l}\text { Low chord } \\
\text { elevation }\end{array}$ & 497.3 & $\mathbf{4 9 7 . 3}$ & $\mathbf{4 9 7 . 6}$ & $\mathbf{4 9 7 . 8}$ & - & - & - & - & - & - & - \\
\hline $\begin{array}{l}\text { Bed } \\
\text { elevation }\end{array}$ & 493.5 & $\mathbf{4 9 2 . 1}$ & $\mathbf{4 9 3 . 3}$ & $\mathbf{4 9 3 . 9}$ & - & - & - & - & - & - & - \\
\hline $\begin{array}{l}\text { Low chord- } \\
\text { bed }\end{array}$ & $\mathbf{3 . 8}$ & $\mathbf{5 . 2}$ & $\mathbf{4 . 3}$ & $\mathbf{3 . 9}$ & - & - & - & - & - & - & - \\
\hline Station & - & - & - & - & - & - & - & - & - & - & - \\
\hline Feature & - & - & - & - & - & - & - & - & - & - & - \\
\hline $\begin{array}{l}\text { Low chord } \\
\text { elevation }\end{array}$ & - & - & - & - & - & - & - & - & - & - & - \\
\hline $\begin{array}{l}\text { Bed } \\
\text { elevation }\end{array}$ & - & - & - & - & - & - & - & - & - & - & - \\
\hline $\begin{array}{l}\text { Low chord- } \\
\text { bed }\end{array}$ & - & - & - & - & - & - & - & - & - & - & - \\
\hline
\end{tabular}

Source (FEMA, VTAOT, Other)?

Comments: -

\begin{tabular}{|l|l|l|l|l|l|l|l|l|l|l|l|}
\hline Station & - & - & - & - & - & - & - & - & - & - & - \\
\hline Feature & - & - & - & - & - & - & - & - & - & - & - \\
\hline $\begin{array}{l}\text { Low chord } \\
\text { elevation }\end{array}$ & - & - & - & - & - & - & - & - & - & - & - \\
\hline $\begin{array}{l}\text { Bed } \\
\text { elevation }\end{array}$ & - & - & - & - & - & - & - & - & - & - & - \\
\hline $\begin{array}{l}\text { Low chord- } \\
\text { bed }\end{array}$ & - & - & - & - & - & - & - & - & - & - & - \\
\hline Station & - & - & - & - & - & - & - & - & - & - & - \\
\hline Feature & - & - & - & - & - & - & - & - & - & - & - \\
\hline $\begin{array}{l}\text { Low chord } \\
\text { elevation }\end{array}$ & - & - & - & - & - & - & - & - & - & - & - \\
\hline $\begin{array}{l}\text { Bed } \\
\text { elevation }\end{array}$ & - & - & - & - & - & - & - & - & - & - & - \\
\hline $\begin{array}{l}\text { Low chord- } \\
\text { bed }\end{array}$ & - & - & - & - & - & - & - & - & - & - & - \\
\hline
\end{tabular}




\section{APPENDIX E: \\ LEVEL I DATA FORM}


U. S. Geological Survey

Bridge Field Data Collection and Processing Form

Qa/Qc Check by: RB Date: $\mathbf{3 / 1 / 9 6}$

Computerized by: $\underline{\mathbf{R B}}$ Date: $3 / 4 / 96$

\section{Structure Number BURKTH00130033}

Reviewd by: $\quad$ RHF Date: 10/1/97

\section{A. General Location Descriptive}

1. Data collected by (First Initial, Full last name) J . DEGNAN

2. Highway District Number $\mathbf{0 7}$

County 005

Waterway (I - 6) ROUNDY BROOK

Route Number TH013

3. Descriptive comments:

This concrete slab bridge is located just DS of bedrock outcrops on a severe bend in the channel. The slab is supported by steel I-beams. The year "1928" is shown in the raised concrete on the US left bank guard rail post. This bridge is located 0.6 mile from the junction of TH013 and TH029.

\section{B. Bridge Deck Observations}
4. Surface cover... LBUS 6
RBUS 6
LBDS 6
RBDS 6
Overall 6

(2b us,ds,lb,rb: 1- Urban; 2- Suburban; 3- Row crops; 4- Pasture; 5- Shrub- and brushland; 6- Forest; 7- Wetland)
5. Ambient water surface... US 2
UB 2
DS $\underline{2}$
(1- pool; 2- riffle)

6. Bridge structure type 1 (1- single span; 2- multiple span; 3- single arch; 4- multiple arch; 5-cylindrical culvert; 6- box culvert; or 7- other)
7. Bridge length $\mathbf{3 0}$
(feet)
Span length $\underline{\mathbf{2 6}}$
(feet)
Bridge width 19.5 (feet)

\section{Road approach to bridge:}
8. LB 1
RB 2
( 0 even, 1- lower, 2- higher)
9. LB_2
RB $\underline{2}$
(1- Paved, 2- Not paved)

10. Embankment slope (run / rise in feet / foot)

US left

US right

\begin{tabular}{|c|c|c|c|}
\hline \multicolumn{2}{|c|}{ Protection } & \multirow{2}{*}{ 13.Erosion } & \multirow{2}{*}{ 14.Severity } \\
\hline 11.Type & 12.Cond. & & \\
\hline 0 & - & $\mathbf{0}$ & $\mathbf{0}$ \\
\hline 2 & 4 & 1 & 3 \\
\hline $\mathbf{0}$ & - & $\mathbf{0}$ & $\mathbf{0}$ \\
\hline 1 & 3 & 3 & 2 \\
\hline
\end{tabular}

Bank protection types: 0- none; 1- < 12 inches;

2- < 36 inches; 3- < 48 inches;

4- < 60 inches; 5- wall / artificial levee

Bank protection conditions: 1- good; 2- slumped;

3- eroded; 4- failed

Erosion: 0 - none; 1- channel erosion; 2

road wash; 3- both; 4- other

Erosion Severity: 0 - none; 1- slight; 2- moderate; 3- severe

\section{Channel approach to bridge (BF):}

15. Angle of approach: $\underline{\mathbf{3 0}}$

16. Bridge skew: 60

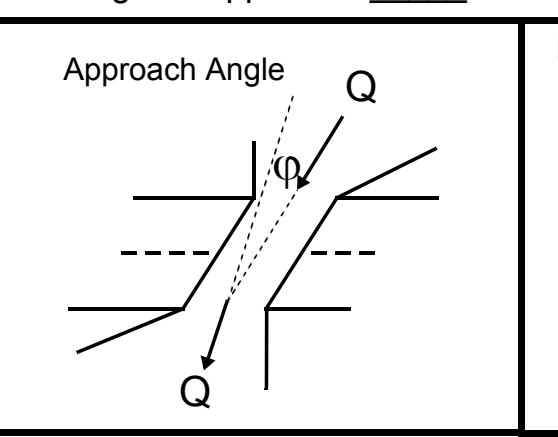

17. Channel impact zone 1 :

Where? RB (LB, RB)

Range? 20 feet $\underline{\text { US }}$

Channel impact zone 2:

Where? LB (LB, RB) Bridge Skew Angle

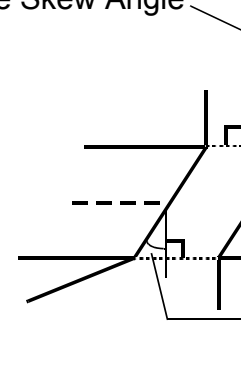

\section{Exist? $\mathbf{Y}(Y$ or $N)$}

Severity 1

$U B, D S)$ to $\underline{45}$ feet $\underline{\text { US }}$

Exist? $\mathbf{Y}(Y$ or $N)$

Severity $\underline{3}$

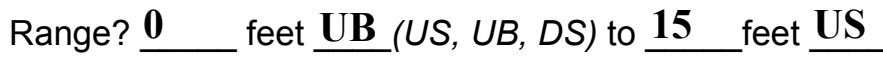

Impact Severity: 0- none to very slight; 1- Slight; 2- Moderate; 3- Severe 
18. Bridge Type: 1a

1a- Vertical abutments with wingwalls

$1 \mathrm{~b}$ - Vertical abutments without wingwalls

2- Vertical abutments and wingwalls, sloping embankment Wingwalls parallel to abut. face

3- Spill through abutments

4- Sloping embankment, vertical wingwalls and abutments

Wingwall angle less than $90^{\circ}$.

19. Bridge Deck Comments (surface cover variations, measured bridge and span lengths, bridge type variations, approach overflow width, etc.)

7. Values are from the VT AOT. Measured bridge length is 30 feet, span length is 26 feet and bridge width is 20 feet.

17. Channel impact zone 1 on the US right bank has a small impact angle but is causing extensive cut-bank damage at the location of the right road embankment.

Channel impact zone 2 impacts the US left bank and has a severe impact angle at the location of the US left wingwall and left abutment.

\section{Upstream Channel Assessment}

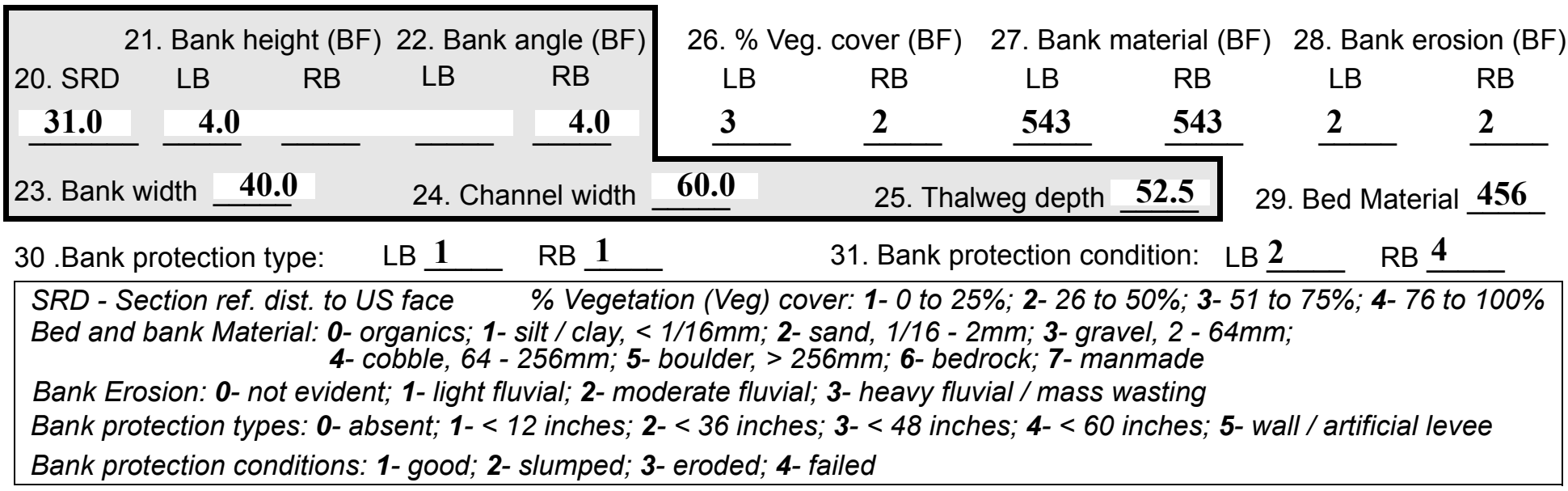

32. Comments (bank material variation, minor inflows, protection extent, etc.):

The bedrock provides a good control for potential channel scour upstream. The upstream channel bed also contains some sand and gravel especially in the vicinity of the point bar. 
33.Point/Side bar present? Y

$(Y$ or N. if $N$ type ctrl-n pb)34. Mid-bar distance: $\mathbf{4 0}$

35. Mid-bar width: 6

36. Point bar extent: 35 feet $\underline{\mathbf{U S}}$

(US, UB) to 78 feet $\underline{\mathbf{U S}}$

(US, UB, DS) positioned $\mathbf{0}$ \%LB to $\mathbf{2 0}$ $\%$ RB

37. Material: 632

38. Point or side bar comments (Circle Point or Side; Note additional bars, material variation, status, etc.):

The point bar is underlain by beds of shist dipping towards the left bank and upstream which help to hold the fine bar material in place. There are also cobbles and boulders on the point bar.

39. Is a cut-bank present? $\mathbf{Y}$ ( $Y$ or if $N$ type ctrl-n $c b)$

41. Mid-bank distance: $\mathbf{2 0}$

42. Cut bank extent: $\mathbf{0}$

40. Where? LB (LB or RB)

43. Bank damage: 1

(1- eroded and/or creep; 2- slip failure; 3- block failure)

44. Cut bank comments (eg. additional cut banks, protection condition, etc.):

The cutbank begins at the US end of the US left wingwall. There is an additional cut bank on the right bank starting at 27 feet US (at the US end of the US right wingwall) and ending at 47 feet US. It has block failure and is cutting into the right road embankment.

\section{Is channel scour present? $\mathbf{Y}$ ( $Y$ or if $N$ type ctrl-n cs)}

47. Scour dimensions: Length 10 Width $\underline{3}$ Depth : 1

46. Mid-scour distance: 0

48. Scour comments (eg. additional scour areas, local scouring process, etc.):

The scour is along the left abutment and US left wingwall footings with the maximum scour depth being at the US bridge face.

49. Are there major confluences? $\mathbf{N}$

51. Confluence 1: Distance Confluence 2: Distance 52. Enters on Enters on 54. Confluence comments (eg. confluence name):

NO MAJOR CONFLUENCES
50. How many? -

53. Type-_ (1- perennial; 2- ephemeral)
Type - (1- perennial; 2- ephemeral) ( $(L B$ or $R B)$ (LB or $R B)$ Position $\underline{0} \%$ LB to $\underline{10} \%$ RB 
65. Debris and Ice Is there debris accumulation?

$(Y$ or $N)$ 66. Where? $\mathbf{N}$

(1- Upstream; 2- At bridge; 3-Both)

67. Debris Potential ( 1- Low; 2- Moderate; 3- High)

68. Capture Efficiency 2

(1-Low; 2- Moderate; 3- High)

69. Is there evidence of ice build-up? 2

Ice Blockage Potential $\mathbf{N}$

(1-Low; 2-Moderate; 3- High)

70. Debris and Ice Comments:

2

The debris potential is moderate due to the large number of trees along the banks. The capture efficiency is moderate because of a low opening height and a sharp skew angle. The ice blockage potential is moderate for the same reasons.

\begin{tabular}{|l|c|c|c|c|c|c|c|c|}
\hline Abutments & $\begin{array}{c}\text { 71. Attack } \\
\angle \mathrm{BF})\end{array}$ & $\begin{array}{c}\text { 72. Slope } \\
(\mathrm{Qmax})\end{array}$ & $\begin{array}{c}\text { 73. Toe } \\
\text { loc. (BF) }\end{array}$ & $\begin{array}{c}\text { 74. Scour } \\
\text { Condition }\end{array}$ & $\begin{array}{c}\text { 75. Scour } \\
\text { depth }\end{array}$ & $\begin{array}{c}\text { 76. Exposure } \\
\text { depth }\end{array}$ & 77. Material & 78. Length \\
\hline LABUT & & $\mathbf{3 0}$ & $\mathbf{9 0}$ & $\mathbf{2}$ & $\mathbf{2}$ & $\mathbf{1 . 0}$ & $\mathbf{1 . 5}$ & $\mathbf{9 0 . 0}$ \\
\hline RABUT & $\mathbf{1}$ & - & $\mathbf{9 0}$ & & & $\mathbf{2}$ & $\mathbf{0}$ & $\mathbf{2 0 . 5}$ \\
\hline
\end{tabular}

Pushed: $L B$ or RB

Toe Location (Loc.): 0- even, 1- set back, 2- protrudes

Scour cond.: 0- not evident; 1- evident (comment); 2- footing exposed; 3-undermined footing; 4- piling exposed; 5- settled; 6- failed

Materials: 1- Concrete; 2- Stone masonry or drywall; 3- steel or metal; 4- wood

79. Abutment comments (eg. undermined penetration, unusual scour processes, debris, etc.):

$-$

1

There is a void between the bottom of the left abutment wall and the top of the left abutment footing.

80. Wingwalls:

Exist? Material? Scour Scour Exposure $\begin{aligned} & 81 . \\ & \text { Angle? Length? }\end{aligned}$ Condition? depth? depth?

USLWW:

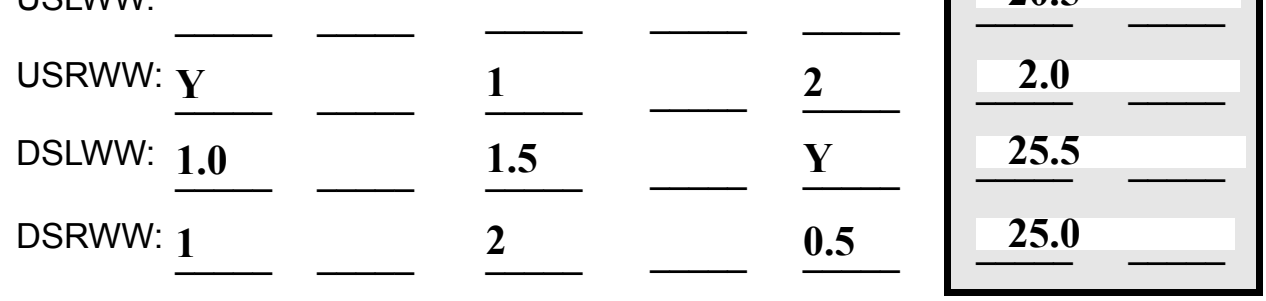

Wingwall materials: 1- Concrete; 2- Stone masonry or drywall; 3- steel or metal; 4- wood

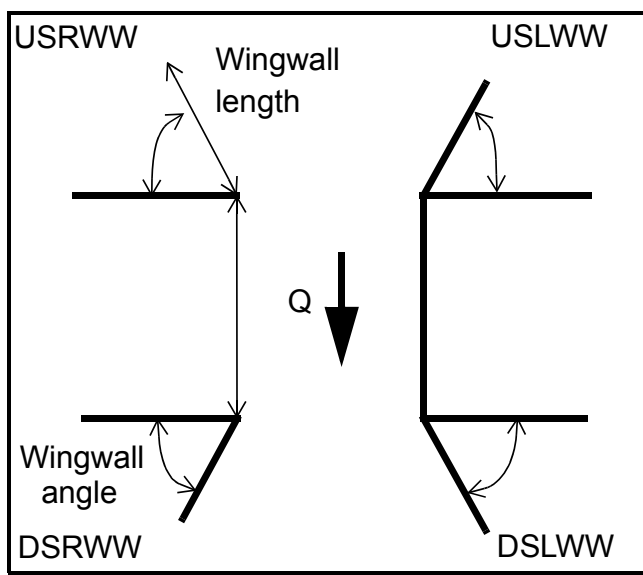

82. Bank / Bridge Protection:

\begin{tabular}{|l|l|l|l|l|l|l|l|l|}
\hline Location & USLWW & USRWW & LABUT & RABUT & LB & RB & DSLWW & DSRWW \\
\hline Type & $\mathbf{1}$ & $\mathbf{2}$ & $\mathbf{Y}$ & - & - & - & - & - \\
\hline Condition & $\mathbf{Y}$ & $\mathbf{0 . 5}$ & $\mathbf{1}$ & - & - & - & - & - \\
\hline Extent & $\mathbf{1}$ & $\mathbf{1}$ & $\mathbf{0}$ & $\mathbf{0}$ & $\mathbf{0}$ & $\mathbf{0}$ & $\mathbf{0}$ & $\mathbf{0}$ \\
\hline
\end{tabular}

Bank / Bridge protection types: 0- absent; 1- < 12 inches; 2- < 36 inches; 3- < 48 inches; 4- < 60 inches; 
83. Wingwall and protection comments (eg. undermined penetration, unusual scour processes, etc.):

$-$

$-$

0

$-$

$-$

0

$-$

0

0

\section{Piers:}

84. Are there piers? Th (Y or if $N$ type ctrl-n pr)

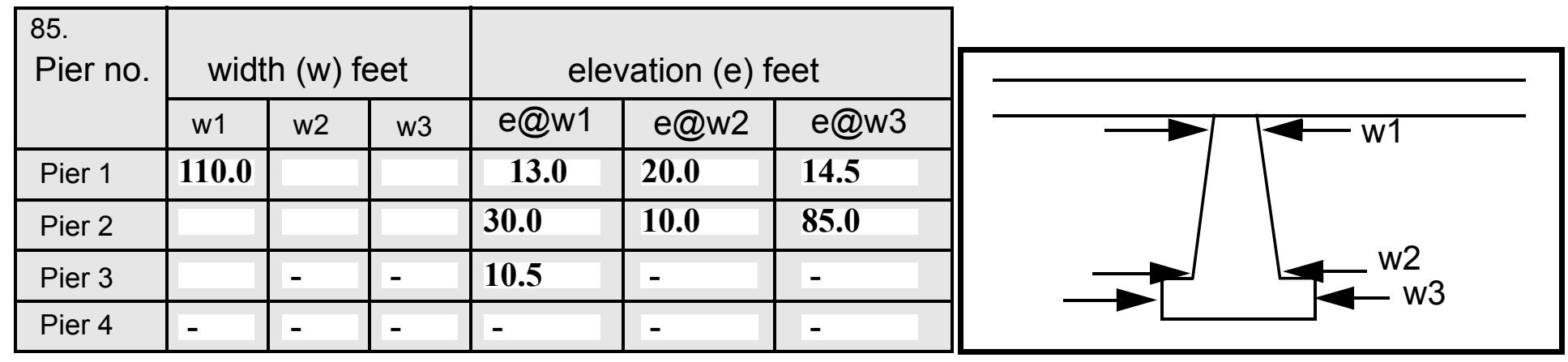

\begin{tabular}{|l|l|l|l|l|}
\hline Level 1 Pier Descr. & \multicolumn{1}{|c|}{1} & \multicolumn{1}{|c|}{2} & 3 & 4 \\
\hline 86. Location (BF) & ere is & the US & & - \\
\hline 87. Type & an & end & & - \\
\hline 88. Material & ero- & of & & - \\
\hline 89. Shape & siona & the & & - \\
\hline 90. Inclined? & I & US & & - \\
\hline 91. Attack $\angle$ (BF) & gully & left & & - \\
\hline 92. Pushed & caus- & wing & N & - \\
\hline 93. Length (feet) & - & - & - & - \\
\hline 94. \# of piles & ing & wall. & - & - \\
\hline 95. Cross-members & bank & & - & - \\
\hline 96. Scour Condition & dam- & & - & - \\
\hline 97. Scour depth & age & & - & - \\
\hline 98. Exposure depth & at & & - & - \\
\hline
\end{tabular}

LFP, LTB, LB, MCL, MCM, MCR, RB, RTB, RFP

1- Solid pier, 2-column, 3- bent

1-Wood; 2- concrete; 3- metal; 4- stone

1- Round; 2- Square; 3- Pointed

Y-yes; $N$ - no

$L B$ or $R B$

0- none; 1- laterals; 2- diagonals; 3- both

0- not evident; 1- evident (comment);

2- footing exposed; 3- piling exposed;

4- undermined footing; 5- settled; 6-failed 
99. Pier comments (eg. undermined penetration, protection and protection extent, unusual scour processes, etc.):

-
-
-
-
-
-
-
-
-
-

100.

\section{E. Downstream Channel Assessment}

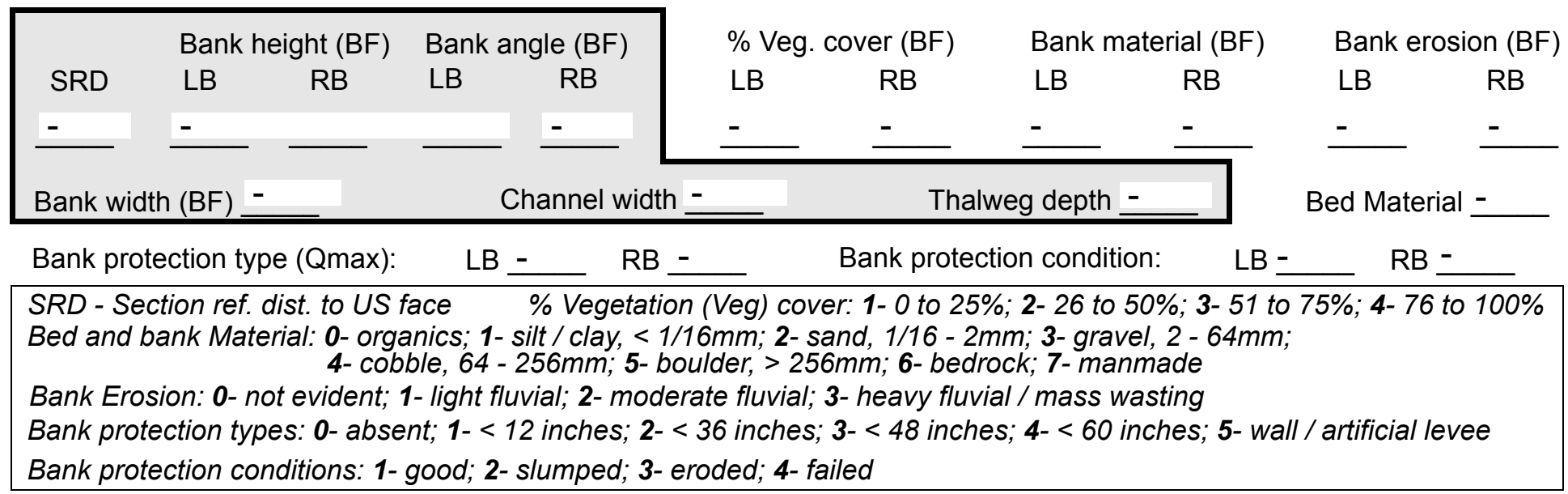

Comments (eg. bank material variation, minor inflows, protection extent, etc.):

-

NO PIERS

101. Is a drop structure present? ( $Y$ or $N$, if $N$ type ctrl-n $d s)$

102. Distance: - feet

103. Drop: - $\quad$ feet 104. Structure material: (1- steel sheet pile; 2- wood pile; 3- concrete; 4- other)

105. Drop structure comments (eg. downstream scour depth): 
106. Point/Side bar present? $\mathbf{5 4}$ (Y or N. if $N$ type ctrl-n pb)Mid-bar distance: $\underline{3}$ Mid-bar width: 1

Point bar extent: $\underline{2}$ feet $\underline{465}$ (US, UB, DS) to $\underline{2}$ feet 0 (US, UB, DS) positioned $\underline{3}$ $\%$ LB to $\% \mathrm{RB}$ Material: At

Point or side bar comments (Circle Point or Side; note additional bars, material variation, status, etc.):

45 feet DS, on the right bank, there is a currently dry minor inflow channel created by road gulley wash. The left bank protection extends from the DS end of the DS left wingwall to 40 feet DS. It has been eroded by channel and road wash with erosion becoming more severe towards the wingwall. The bank and bed also contain some interstitial sand.

Is a cut-bank present? (Y or if $N$ type ctrl-n cb) Where? (LB or $R B)$

Mid-bank distance:

Cut bank extent: feet (US, UB, DS) to feet (US, UB, DS)

Bank damage: (1- eroded and/or creep; 2- slip failure; 3- block failure)

Cut bank comments (eg. additional cut banks, protection condition, etc.):

$\mathbf{N}$

Is channel scour present? (Y or if $N$ type ctrl-n cs)

Mid-scour distance: NO

Scour dimensions: Length $\underline{\text { DRO }}$ Width $\underline{\mathbf{P}}$ Depth: STR

Positioned UC \%LB to $\underline{\text { TU }} \%$ RB

Scour comments (eg. additional scour areas, local scouring process, etc.):

RE

Are there major confluences? ( $Y$ or if $N$ type ctrl-n $m c)$

How many?

Confluence 1: Distance $\underline{\mathbf{Y}}$ Enters on $\underline{\mathbf{0}}$ (LB or RB)

Type 9 (1- perennial; 2- ephemeral)

Confluence 2: Distance $\mathbf{0}$ Enters on $\underline{\mathbf{U S}}$ (LB or RB)

Type $\underline{5}$ (1- perennial; 2- ephemeral)

Confluence comments (eg. confluence name):

DS

60

\section{F. Geomorphic Channel Assessment}

107. Stage of reach evolution

1- Constructed

2- Stable

3- Aggraded

4- Degraded

5- Laterally unstable

6- Vertically and laterally unstable 
108. Evolution comments (Channel evolution not considering bridge effects; See HEC-20, Figure 1 for geomorphic descriptors):

324

This point bar is noted in the historical form.

Y

RB

45

20

DS

80

DS

1 


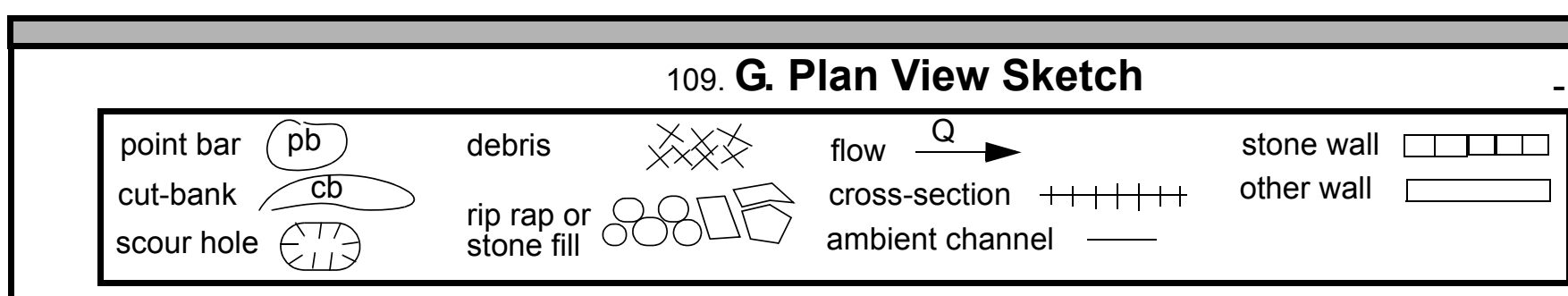

cut-bank $\mathrm{cb}$

scour hole rip rap or
stone fill stone fill cross-section $+1+1+1$ ambient channe other wall 
APPENDIX F:

SCOUR COMPUTATIONS 
SCOUR COMPUTATIONS

\begin{tabular}{|c|c|c|c|}
\hline $\begin{array}{ll}\text { Structure Number: } & \text { BURKTH00130033 } \\
\text { Road Number: } & \text { TH } 13\end{array}$ & & $\begin{array}{l}\text { Town: } \\
\text { County: }\end{array}$ & $\begin{array}{l}\text { Burke } \\
\text { Caledonia }\end{array}$ \\
\hline Stream: Roundy Brook & & & \\
\hline Initials RHF & Checked: & SAO & \\
\hline $\begin{array}{l}\text { Analysis of contraction scour, live } \\
\text { Critical Velocity of Bed Material } \\
\text { VC=11.21*y1^0.1667*D50^0.33 with Ss } \\
\text { (Richardson and others, 1995, p. } 28\end{array}$ & $\begin{array}{l}\text {-bed or } \mathrm{C} \\
\text { converted } \\
=2.65 \\
\text {, eq. 16) }\end{array}$ & $\begin{array}{l}\text { lear wate } \\
\text { to Engli }\end{array}$ & $\begin{array}{l}\text { s? } \\
\text { sh units) }\end{array}$ \\
\hline pproach section & & & \\
\hline Characteristic & $100 \mathrm{yr}$ & $500 \mathrm{yr}$ & other $\mathrm{Q}$ \\
\hline Total discharge, cfs & 1490 & 2100 & 770 \\
\hline Main Channel Area, ft2 & 247 & 274 & 175.6 \\
\hline Left overbank area, ft2 & 0 & 0 & 0 \\
\hline Right overbank area, ft2 & 0 & 7 & 0 \\
\hline Top width main channel, ft & 41 & 42 & 35 \\
\hline Top width L overbank, ft & 0 & 0 & 0 \\
\hline Top width $\mathrm{R}$ overbank, ft & 0 & 31 & 0 \\
\hline D50 of channel, ft & 0.32483 & 0.32483 & 0.32483 \\
\hline D50 left overbank, ft & -- & -- & -- \\
\hline D50 right overbank, ft & -- & -- & -- \\
\hline $\mathrm{Y}_{1}$, average depth, $\mathrm{MC}$, ft & 6.0 & 6.5 & 5.0 \\
\hline $\mathrm{y}_{1}$, average depth, LOB, ft & ERR & ERR & ERR \\
\hline $\mathrm{Y}_{1}$, average depth, ROB, ft & ERR & 0.2 & ERR \\
\hline Total conveyance, approach & 18569 & 21825 & 11715 \\
\hline Conveyance, main channel & 18569 & 21735 & 11715 \\
\hline Conveyance, LOB & 0 & 0 & 0 \\
\hline Conveyance, ROB & 0 & 90 & 0 \\
\hline Percent discrepancy, conveyance & 0.0000 & 0.0000 & 0.0000 \\
\hline Qm, discharge, MC, cfs & 1490.0 & 2091.3 & 770.0 \\
\hline Q1, discharge, LOB, cfs & 0.0 & 0.0 & 0.0 \\
\hline Qr, discharge, ROB, cfs & 0.0 & 8.7 & 0.0 \\
\hline Vm, mean velocity $\mathrm{MC}$, ft/s & 6.0 & 7.6 & 4.4 \\
\hline Vl, mean velocity, LOB, ft/s & ERR & ERR & ERR \\
\hline Vr, mean velocity, ROB, ft/s & ERR & 1.2 & ERR \\
\hline Vc-m, crit. velocity, MC, ft/s & 10.4 & 10.5 & 10.1 \\
\hline Vc-l, crit. velocity, LOB, ft/s & $\mathrm{ERR}$ & $\mathrm{ERR}$ & $\mathrm{ERR}$ \\
\hline Vc-r, crit. velocity, ROB, ft/s & ERR & ERR & ERR \\
\hline Results & & & \\
\hline Live-bed(1) or Clear-Water(0) Contr & action $\mathrm{Sc}$ & our? & \\
\hline Main Channel & 0 & 0 & 0 \\
\hline Left Overbank & $\mathrm{N} / \mathrm{A}$ & $\mathrm{N} / \mathrm{A}$ & $\mathrm{N} / \mathrm{A}$ \\
\hline Right Overbank & $\mathrm{N} / \mathrm{A}$ & $\mathrm{N} / \mathrm{A}$ & $\mathrm{N} / \mathrm{A}$ \\
\hline
\end{tabular}

Armoring

$\mathrm{DC}=\left[\left(1.94 * \mathrm{~V}^{\wedge} 2\right) /(5.75 * \log (12.27 * \mathrm{Y} / \mathrm{D} 90))^{\wedge} 2\right] /[0.03 *(165-62.4)]$

Depth to Armoring $=3 *(1 / \mathrm{PC}-1)$

(Federal Highway Administration, 1993)

Downstream bridge face property 100-yr 500-yr Other 0

Q, discharge thru bridge MC, Cfs $1065 \quad 1049 \quad 770$

Main channel area (DS), ft2 $\quad 97 \quad 97$ 


\begin{tabular}{|c|c|c|c|}
\hline Main channel width (normal), ft & 20.3 & 20.3 & 20.3 \\
\hline Cum. width of piers, ft & 0.0 & 0.0 & 0.0 \\
\hline Adj. main channel width, ft & 20.3 & 20.3 & 20.3 \\
\hline D90, ft & 0.8142 & 0.8142 & 0.8142 \\
\hline D95, ft & 1.1001 & 1.1001 & 1.1001 \\
\hline Dc, critical grain size, ft & 0.6661 & 0.6462 & 0.4972 \\
\hline PC, Decimal percent coarser than DC & 0.178 & 0.189 & 0.293 \\
\hline epth to armoring, & 9.26 & 8.31 & 3.61 \\
\hline
\end{tabular}

Clear water Contraction Scour in MAIN CHANNEL

$\mathrm{y} 2=\left(\mathrm{Q} 2^{\wedge} 2 /\left(131 * \operatorname{Dm}^{\wedge}(2 / 3) * \mathrm{~W} 2^{\wedge} 2\right)\right)^{\wedge}(3 / 7) \quad$ Converted to English Units

ys $=\mathrm{y}^{2}-\mathrm{Y} \_$bridge

(Richardson and others, 1995, p. 32, eq. 20, 20a)

Bridge Section $\quad$ Q100 0500

(Q) total discharge, cfs $1490 \quad 2100$ Other

(Q) discharge thru bridge, cfs $1065 \quad 1049 \quad 770$

Main channel conveyance $4971 \quad 4971 \quad 4971$

Total conveyance $\quad 4971 \quad 4971 \quad 4971$

Q2, bridge MC discharge, cfs $\quad 1065 \quad 1049 \quad 770$

Main channel area, ft2 $\quad 97 \quad 97 \quad 97$

Main channel width (normal), ft $20.3 \quad 20.3 \quad 20.3$

Cum. width of piers in MC, ft $0.0 \quad 0.0 \quad 0.0$

$\begin{array}{llll}W, \text { adjusted width, ft } & 20.3 & 20.3 & 20.3\end{array}$

Y_bridge (avg. depth at br.), ft $4.78 \quad 4.78 \quad 4.78$

Dm, median (1.25*D50), ft 0.4060380 .4060380 .406038

Y2, depth in contraction, ft $\quad \begin{array}{rrrr}4.77 & 4.71 & 3.61\end{array}$

ys, scour depth (y2-ybridge), ft $\begin{array}{llll}-0.01 & -0.07 & -1.17\end{array}$

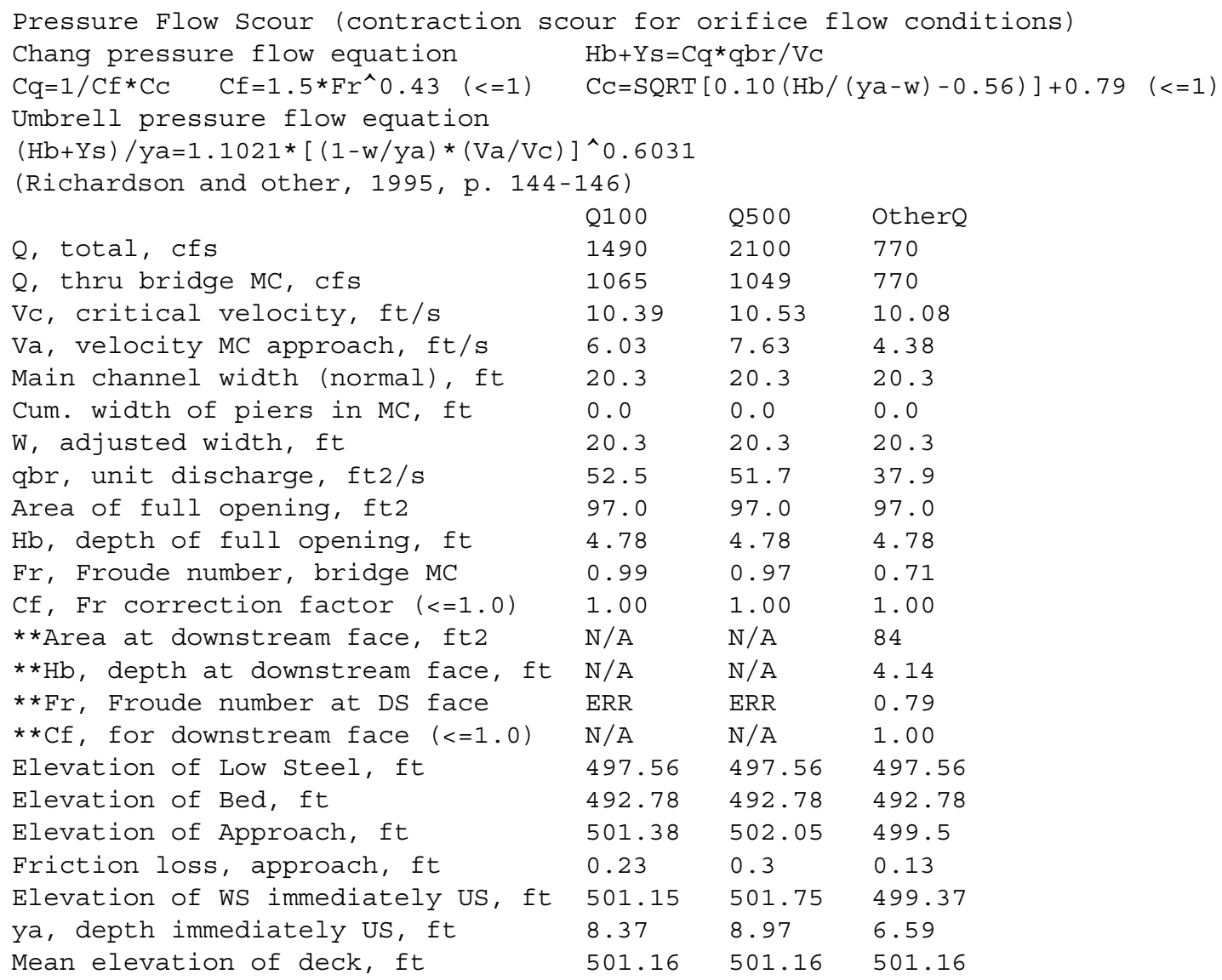




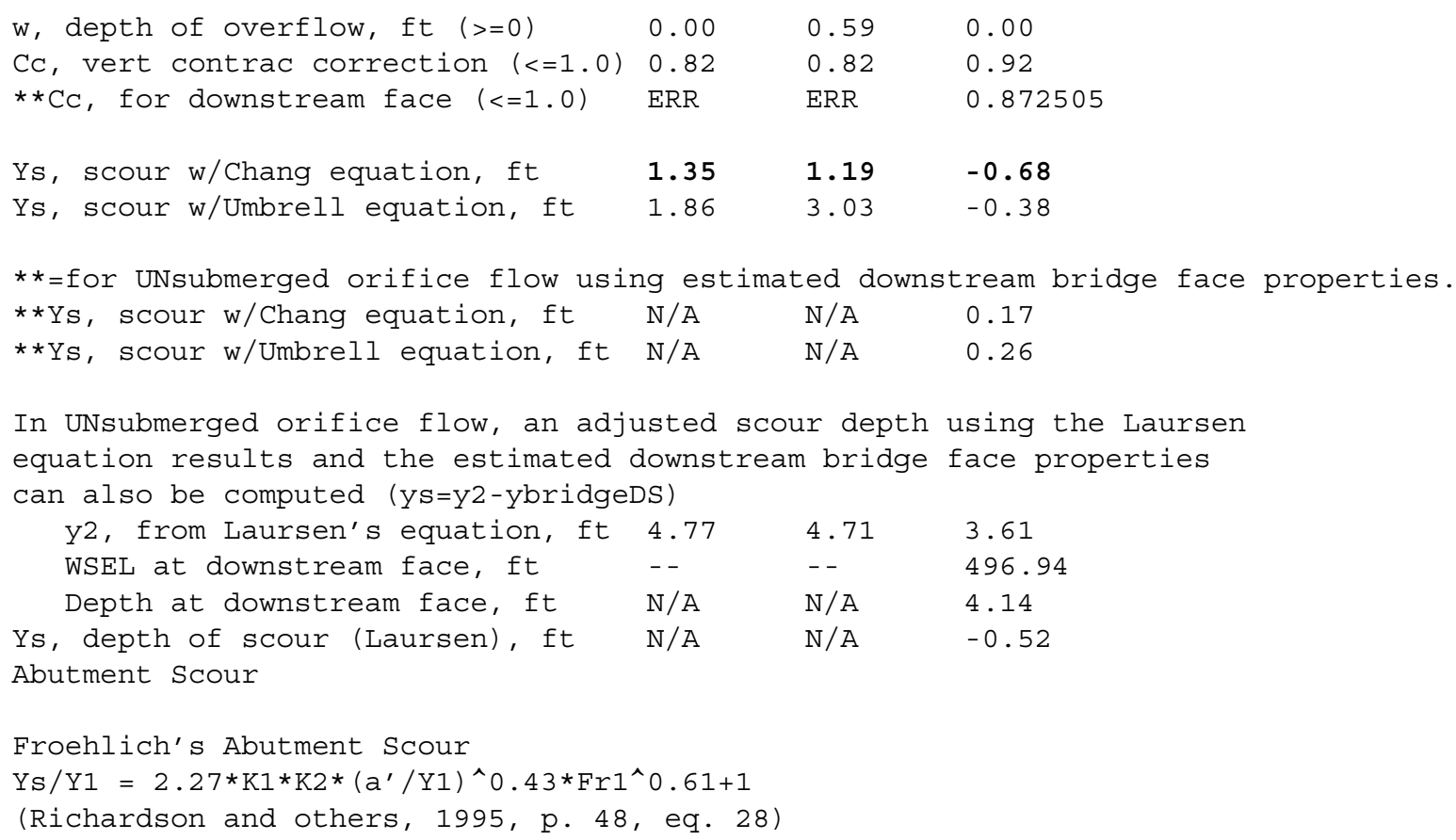


Abutment riprap sizing

Isbash Relationship

$\mathrm{D} 50=\mathrm{Y} * \mathrm{~K} * \mathrm{Fr} \wedge 2 /(\mathrm{Ss}-1)$ and $\mathrm{D} 50=\mathrm{Y} * \mathrm{~K} *\left(\mathrm{Fr}{ }^{\wedge} 2\right)^{\wedge} 0.14 /(\mathrm{Ss}-1)$

(Richardson and others, 1995, p112, eq. 81,82)

\begin{tabular}{|c|c|c|c|c|c|c|}
\hline Characteristic & Q100 & Q500 & Other $\mathrm{Q}$ & Q100 & Q500 & Other $\mathrm{Q}$ \\
\hline Fr, Froude Number & 0.99 & 0.97 & 0.79 & 0.99 & 0.97 & 0.79 \\
\hline y, depth of flow in bridge, ft & 4.76 & 4.76 & 4.14 & 4.76 & 4.76 & 4.14 \\
\hline Median Stone Diameter for riprap & $t:$ left & 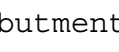 & & right & abutment & ft \\
\hline Fr< $<=0.8$ (vertical abut.) & ERR & ERR & 1.60 & ERR & ERR & 1.60 \\
\hline Fr>0.8 (vertical abut.) & 1.98 & 1.97 & ERR & 1.98 & 1.97 & ERR \\
\hline
\end{tabular}

